\title{
Mineração industrial na Amazônia e suas implicações para o desenvolvimento regional*
}

Maurílio de Abreu Monteiro - Professor e pesquisador do Núcleo de Altos Estudos Amazônicos da UFPA

\section{Resumo}

Embora a mercantilização de recursos minerais na Amazônia oriental brasileira tenha envolvido a comercializa-ção, por mais de cinco décadas, de mercadorias bastante diversas, extraídas e transformadas industrialmente por empresas que foram instaladas em momentos históricos distintos, suas repercussões no desenvolvimento de certas áreas da região guardam importantes singularidades e têm lógicas e características, em grande parte, comuns. O trabalho sintetiza os macrocenários nos quais se instalaram empresas mínero-metalúrgicas e analisa as razões das limitações que as atividades desenvolvidas por essas empresas têm para impulsionar dinâmicas de desenvolvimento amplas e socialmente enraizadas.

\section{Abstract}

The commercial development of mineral resources in the eastern Brazilian Amazon has taken place over the last five decades. In spite of the range of minerals that have been extracted and processed and the different historical periods, the repercussions of the development of certain regional areas have certain important specificities and have a certain logic and characteristics in common. This article synthesizes the macro-level scenarios in which mineral extraction and transformation companies have become established in the region. It also analyzes the limitations of the development of such activities have with respect to promoting and fostering broad and socially rooted development.

\section{Palavras-chave}

Amazônia, mineração, metalurgia, desenvolvimento regional.

\section{Keywords}

Amazonia, Mining, Metallurgy, Regional Development.

\footnotetext{
"A elaboração deste artigo contou com a colaboração do CNPq.
} 


\section{INTRODUÇÃO}

Desde os anos 50 do século XX, a extração e a transformação industrial de minerais acalentaram, em amplos e diversos segmentos sociais, expectativas de rápida modernização e desenvolvimento de áreas da Amazônia oriental brasileira impulsionadas pela demanda global de mercadorias de origem mineral. Tais convicções justificaram a implementação de ações estatais para favorecer a exploração industrial de minérios na região.

Nos governos militares, além do estabelecimento de políticas de incentivo à instalação de grandes empresas mineradoras na região, também houve grande apoio estatal para que os minérios lavrados regionalmente tivessem sua cadeia de transformação industrial estabelecida na Amazônia oriental (ALMEIDA JR., 1986; HALL, 1991; CASTRO; MOURA; MAIA, 1994; D'INCAO; SILVEIRA, 1994; MACHADO, 1985; COELHO; COTA, 1997; MONTEIRO, 1998).

Tais ações assumiram a condição de elemento axiomático nas tentativas estratégicas de modernização da Amazônia por meio de programas governamentais, como o Programa de Pólos Agropecuários e Agrominerais da Amazônia (SUDAM, 1975) e o Programa Grande Carajás (BRASIL, 1982). Inspirados em noções teóricas que preconizavam a necessidade da intervenção direta do Estado como forma de induzir o desenvolvimento em áreas geográficas selecionadas (HIRSCHMAN, 1958; PERROUX, 1967) por meio da concentração espacial de capitais, esses programas estariam aptos a efetivar a verticalização da produção industrial de bens minerais - considerados detentores de grandes "vantagens comparativas" (SUDAM, 1976).

Na década de 90, houve uma mudança significativa nos discursos e nas práticas do Estado brasileiro em relação às políticas de desenvolvimento regional, expressas em novas estratégias de desenvolvimento presentes nos Programas "Brasil em Ação" e "Avança Brasil". Passou-se a advogar a necessidade do estabelecimento de "eixos de integração", que possibilitariam um acesso mais competitivo a mercados (BRASIL, 1997b). Seguindo essa lógica, foi mantido, para a região, o destaque para as "vantagens comparativas" das mercadorias de origem mineral (BRASIL, 1997a). Essas estratégias, em seu conjunto e em relação às predições iniciais, produziram efeitos muito limitados no que concerne à integração vertical da produção mineral.

Nos itens seguintes, são indicados os cenários e as dinâmicas que impulsionaram a implantação, nos últimos 50 anos, de empresas destinadas à extração e à transformação de minerais na região; são ainda 
apontadas as possíveis limitações que a mínero-metalurgia tem para impulsionar processos de desenvolvimento de áreas da Amazônia oriental brasileira.

\section{A PRIMEIRA EXPERIÊNCIA DE MINERAÇÃO INDUSTRIAL EM LARGA ESCALA NA AMAZÔNIA}

A exploração industrial de minérios na região remonta aos anos 40 do século passado, período em que se descobriram jazidas de minério de manganês na Serra do Navio, no então Território Federal do Amapá, desmembrado do Estado do Pará em 1943.

Naquela época, o minério de manganês era considerado estratégico (CUNHA, 1962, p. 22), pois a antiga União Soviética, detentora de grandes reservas mundiais de manganês - insumo que, apesar de utilizado em pequena quantidade, se comparado ao ferro, é indispensável à indústria do aço -, havia suspendido a sua venda. Por essa razão, as reservas da Serra do Navio ganharam enorme importância, sendo inclusive declaradas, em 1946, por decreto do presidente Eurico Dutra, como "reserva nacional".

Para a valorização - entendida como agregação de valor e conversão de recursos minerais em mercadoria - da jazida, estabeleceu-se concorrência, que foi vencida pela Indústria e Comércio de Minérios S.A. (ICOMI), uma empresa brasileira de médio porte. Em 1947, ela recebeu autorização do Governo Federal para pesquisar e explorar o manganês. Em 1950, sob a alegação da necessidade de aporte técnico e de recursos financeiros, a Icomi associou-se à Bethlehem Steel Corp. - naquele período uma das maiores corporações norte-americanas produtoras de aço (CHANDLER, 1977, p. 360) -, que passou a participar com 49\% do capital da empresa. Essa mudança deixou evidente quem a Icomi representava. Nos anos seguintes, é dada continuidade à pesquisa geológica, e edificam-se os equipamentos de infra-estrutura, que envolviam as instalações industriais para a mineração e o beneficiamento do minério (Figura 1): a estrada de ferro, com aproximadamente $200 \mathrm{~km}$, as instalações portuárias, além de duas company towns (núcleos residenciais para funcionários), uma em Serra do Navio e outra em Santana (Figura 1). Essas vilas, diga-se de passagem, foram tomadas como referência de company town, balizando a organização da moradia dos funcionários de diversas empresas mínero-metalúrgicas posteriormente instaladas na Amazônia. 
A valorização daquelas minas esteve submetida a um contrato de arrendamento, cuja versão definitiva foi aprovada, em 1950, pelo Congresso Nacional, apesar dos diversos questionamentos em relação ao favorecimento de interesses privados em detrimento dos de caráter público (CUNHA, 1962, p. 10). O Estado também patrocinou uma série de favores, não exigidos contratualmente, em benefício da Icomi, visto que a perspectiva de operação da empresa e os termos do arrendamento eram apontados no discurso oficial e de amplos setores da sociedade como fundamentais para o desenvolvimento do Amapá, especialmente pelo fato de o contrato estabelecer que a Icomi deveria pagar ao governo do Amapá 4\% do valor de venda do minério, bem como deveria investir, em novas empresas no território, 20\% dos lucros líquidos originados da exploração das minas arrendadas. A própria Presidência da República, a propósito da obtenção de financiamento para a Icomi, declarava, em 1953, que o projeto era "economicamente vantajoso do ponto de vista nacional" (ICOMI, [1977?], p. 3).

Em 1957 foi efetivado o primeiro embarque de minério, atividade que se estendeu por quatro décadas, até 1997, quando a empresa encerrou suas atividades e declarou exauridas as reservas (Figura 1).

\section{GOVERNOS MILITARES, INTERESSES GEOPOLÍTICOS E MINERAÇÃO NA AMAZÔNIA}

O minério de manganês da Serra do Navio permaneceu por aproximadamente duas décadas como a única extração mineral industrial significativa na Amazônia oriental brasileira. Um quadro que vai se modificar significativamente, em decorrência das políticas desencadeadas pelo golpe militar de 1964. O Estado autoritário, a partir da convergência da geopolítica com a doutrina de segurança nacional, formulou uma doutrina de intervenção interna, que tomou formas específicas no caso da Amazônia. Era imperioso "ocupar" a Amazônia, na visão dos principais segmentos dos governos militares. Buscou-se isso por meio de políticas de desenvolvimento que pressupunham a firme articulação de interesses privados, em que se enquadravam as grandes empresas do campo da mínero-metalurgia.

Um grande aparato institucional voltado para a consecução de tais políticas foi criado, e dele faziam parte a Superintendência de Desenvolvimento da Amazônia (SUDAM) e o Banco da Amazônia (BASA). Ampliou-se também a política de incentivos fiscais para a região. Além disso, o Governo Federal realizou significativos investimentos no 
levantamento de dados sobre as características físicas da região, no que teve grande destaque o Projeto Radares da Amazônia (RADAM), cujos resultados permitiram a indicação de possíveis alternativas para a construção de estradas e usinas hidrelétricas e o incremento das pesquisas geológicas na Amazônia. Ressalte-se que, naquele momento, essas pesquisas já eram realizadas sob o novo Código de Mineração de 1967, que retirou o direito de preferência da exploração mineral do proprietário da terra e tornou ilegal a garimpagem, medidas que atendiam aos interesses das grandes empresas mineradoras (BRASIL, 1987).

\subsection{A criação do Programa de Pólos Agropecuários e Agromi- nerais da Amazônia}

Com o decorrer dos primeiros anos da década de 70, os fundamentos sobre os quais se assentava o modelo de desenvolvimento implementado nacionalmente pelos militares apresentavam sinais de fadiga, sendo perceptíveis indicações de possíveis reduções na taxa de crescimento econômico. O Governo Federal pretendia manter elevadas as taxas de crescimento econômico por meio de investimentos na indústria responsável pela produção de bens de capital. Para tanto necessitava de recursos financeiros. Assim se projetaram para a Amazônia ações estatais direcionadas ao fomento e à criação de projetos que entrassem em funcionamento com relativa rapidez e que produzissem em larga escala. A produção era destinada ao mercado externo, o que ampliava a importância da valorização - entendida como incorporação de valor, conversão em mercadorias - dos recursos minerais da Amazônia enquanto geradores de divisas e recursos para financiar os planos do Governo.

Para agilizar a implantação de projetos exportadores, o Governo Federal criou, em 1974, o Programa de Pólos Agropecuários e Agrominerais da Amazônia (POLAMAZÔNIA). Os planos federais previam a implantação de diversos "pólos de desenvolvimento na Amazônia brasileira", com destaque para a produção mineral. Pretendia o Governo Federal direcionar os impactos da política de incentivos fiscais para áreas geográficas selecionadas, concentrando nelas também suas ações de construção de infra-estrutura, com a finalidade de propiciar investimentos maciços e espacialmente concentrados. Essas ações ancoravam-se, portanto, numa visão de desenvolvimento regional que tinha por fundamento a necessidade de concentração espacial de capitais, capazes de produzir desequilíbrios e, por conseguinte, impulsionar um processo de desenvolvimento de atividades por meio de uma cadeia de ligações para frente e para trás das atividades 
Maurilio de Abreu Monteiro

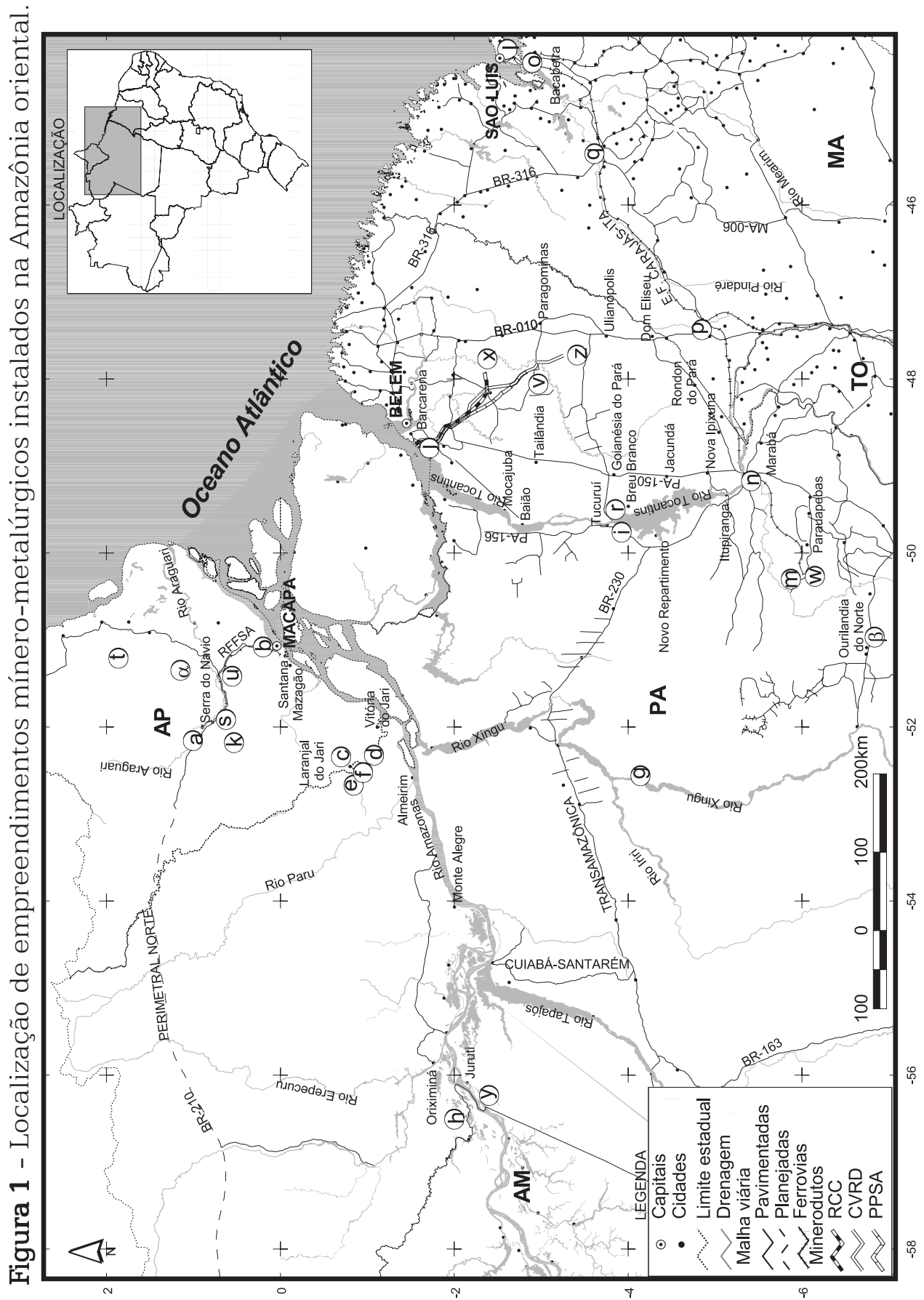



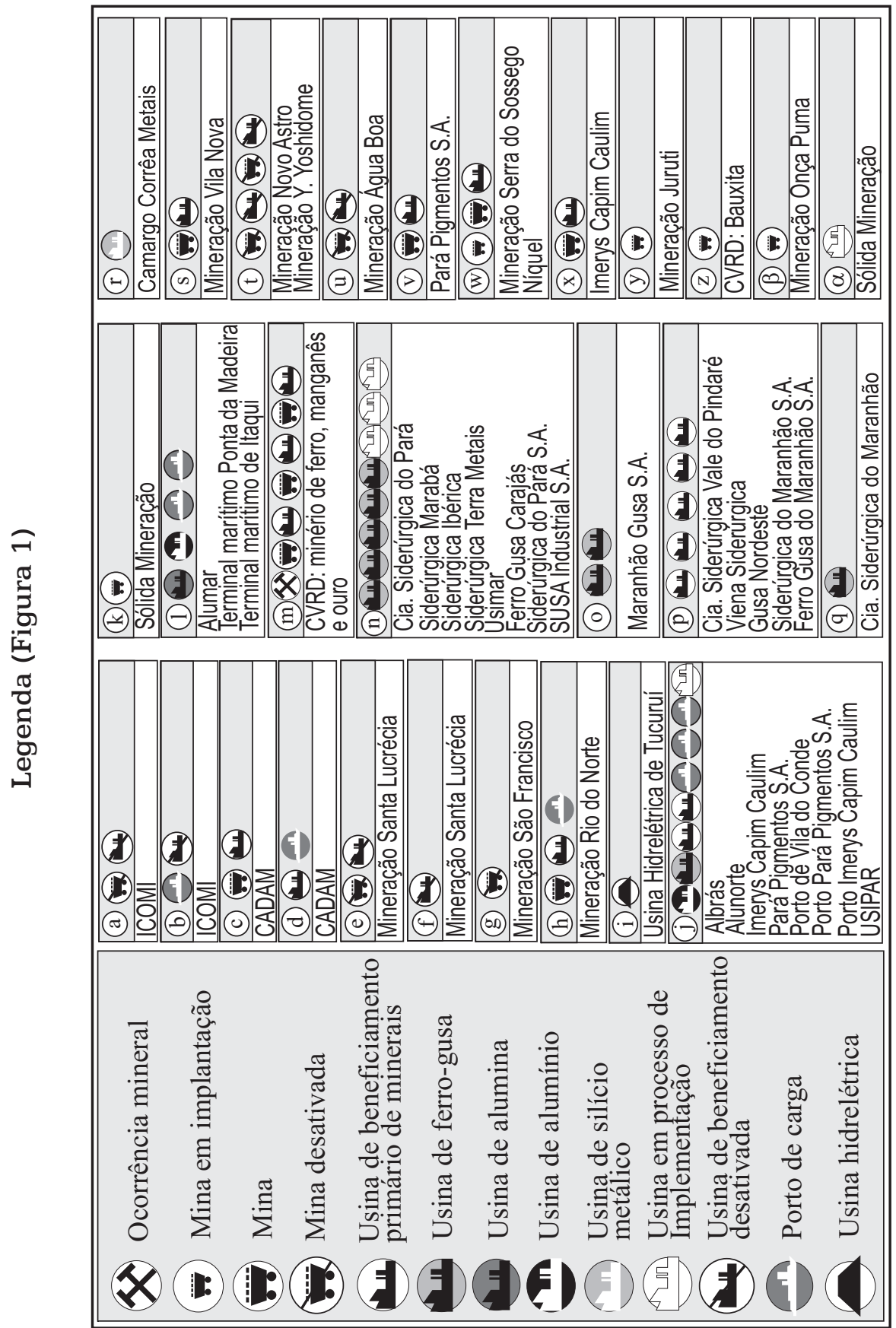
produtivas consideradas "chaves". Alguns dos pólos que integravam o Polamazônia foram Carajás, Trombetas e Amapá.

No pólo do Amapá, a política de incentivos fiscais foi utilizada pela Icomi para implantar uma usina de pelotização, visando ao aproveitamento da parcela muito fina de minério de manganês. Os recursos públicos decorrentes da utilização de incentivos fiscais arcaram com aproximadamente 50\% dos custos da implantação da indústria (ICOMI, [1977?], p. 17). A usina foi instalada em Santana, no Amapá (Figura 1), entrou em operação em 1973 e, apesar de ter capacidade nominal para 210 mil toneladas/ano, a produção de pelotas atingiu no máximo 184 mil toneladas/ano em 1980.

Na área do pólo Amapá, também entrou em operação a primeira empresa dedicada à extração industrial de caulim na Amazônia oriental brasileira. Tratava-se da Caulim da Amazônia (CADAM), criada como parte dos investimentos do milionário norte-americano Daniel Ludwig na área da Jari Florestal - um dos primeiros projetos concebidos durante o regime militar como uma maneira de "ocupar"aceleradamente a região.

As reservas de caulim na região foram descobertas em função da necessidade de calcário para realizar a correção da acidez de solos no Projeto Jari, onde se plantam eucaliptos para a produção de celulose. Tal carência determinou o início de estudos geológicos na região com o objetivo de verificar a existência daquele minério (HALWARD et al., 1977, p. 83). De tais pesquisas decorreu a descoberta de excelentes jazidas de caulim numa área conhecida como morro do Felipe, situada na margem esquerda do rio Jari, atualmente município de Laranjal do Jari, Amapá (Figura 1).

A Cadam passou então a explorar o caulim, um mineral que tem diversas utilidades industriais. O que é extraído na Amazônia oriental brasileira, em virtude de sua excelente qualidade, tem a mais nobre aplicação de todas elas: a de servir como material de cobertura da superfície de papéis, tornando-o mais claro e menos translúcido. Em 1977, a Cadam iniciou a lavra na área do morro do Felipe. A Cadam explora a mina de caulim e realiza o seu beneficiamento primário no Estado do Amapá, mas o minério é transportado por um mineroduto que passa sob o rio Jari, para, então, ser processado na usina que se localiza no município paraense de Almeirim, onde o produto é então embarcado em navios no porto da própria empresa (Figura 1).

Em 1982, o controle acionário da Cadam foi assumido pela Caemi Mineração e Metalurgia S.A., de Trajano de Azevedo Antunes, também proprietário da Icomi. Uma transação na qual o Estado nacional, em consonância com sua política, injetou recursos e estabeleceu favores 
tributários. A Cadam passou, por conseguinte, a contar com a participação acionária, além da Caemi, do Banco do Brasil e do BNDES, como também a ser beneficiada, por meio da Sudam, por incentivos fiscais, como a isenção de Imposto de Renda (IR). Após três ampliações nas suas instalações, a empresa atualmente conta com uma capacidade instalada de atender à demanda de 850 mil toneladas/ano (Figura 2B), havendo perspectivas de ampliação dessa capacidade para 1,1 milhão de toneladas/ano.

Em 2001, no bojo da aquisição do patrimônio da Caemi pela Companhia Vale do Rio Doce (CVRD), o controle acionário da Cadam foi transferido para esta última.

Além da Cadam, o grupo de Azevedo Antunes também adquiriu a Mineração Santa Lucrécia Minerais S.A. (MSL Minerais), criada em 1971, também como parte dos investimentos de Ludwig na área da Jari Florestal, com a finalidade de explorar reservas de bauxita refratária às proximidades do rio Jari (Figura 1). A sua produção iniciou-se em escala experimental, em 1981. Entretanto, com o processo de transferência do patrimônio de Ludwig, sua operação voltada para o atendimento do mercado só se efetivou no final de 1984.

Em 1998, foram incorporadas à empresa novas instalações de beneficiamento, que elevaram a sua capacidade de produção até 260 mil toneladas/ano de bauxita refratária crua - produto que, nas indústrias de refratários, é utilizado em revestimento de fornos. No início da década de 90, por decisão da Sudam, a empresa passou a gozar de isenção do pagamento de IR por dez anos, o que ocorreu concomitantemente à instalação da sua usina de calcinação, com capacidade de produção de 60 mil toneladas/ano de bauxita refratária calcinada. Essa usina situase a $66 \mathrm{~km}$ das minas, às margens da ferrovia da Jari Florestal, no município de Almeirim (Figura 1). A empresa inicia, então, a produção da bauxita calcinada, cujo valor de mercado é superior ao da bauxita refratária crua. Três anos mais tarde, entra em operação o segundo forno da usina de calcinação, possibilitando à MSL Minerais produzir até 150 mil toneladas/ano de bauxita calcinada, produção escoada pelos trilhos da estrada de ferro até o porto da Cadam, onde é embarcada.

Cabe referência também ao desenvolvimento, na Amazônia oriental brasileira, de atividades voltadas para a exploração industrial de cassiterita - minério de estanho - decorrente da operação de minas de pequeno porte, vinculadas, entretanto, a grupos do ramo da metalurgia. O grupo Paranapanema, maior produtor nacional de estanho, operou a partir de suas subsidiárias as minas de São Raimundo, e o 
grupo CANOPUS operou, por meio da Mineração São Francisco, as minas de Mocambo e São Pedro do Iriri, localizadas no município de Altamira, Pará, às margens do rio Xingu (Figura 1). A produção de cassiterita, apesar da constância, não chegou a ter relevância no cenário regional. Em 1994, todas as minas importantes foram fechadas, passando então a produção a concentrar-se no Amazonas e em Rondônia.

\subsubsection{A exploração da bauxita da região do Trombetas}

Foi também naquele cenário dos anos 70 que se desenharam as condições que viabilizaram a extração e a comercialização da bauxita metalúrgica na Amazônia brasileira, mais especificamente as jazidas que haviam sido descobertas, ainda na década de 60, às proximidades do rio Trombetas, no município paraense de Oriximiná (Figura 1), pela empresa Bauxita Santa Rita Ltda., subsidiária da empresa canadense Aluminium Limited of Canada (ALCAN).

A bauxita metalúrgica é o alumínio na forma de minério. Para ser convertida em alumínio, é necessário que a bauxita, depois de extraída e submetida ao beneficiamento primário, seja submetida a um processo de refino químico, do qual resulta a alumina, um pó branco, que servirá como principal insumo para a produção do alumínio.

Para a valorização da jazida de bauxita metalúrgica da região do Trombetas, foi criada, em 1967, a Mineração Rio do Norte (MRN). Entretanto, em 1972, a Alcan, alegando condições desfavoráveis ao produto no mercado mundial, paralisou o projeto. Na verdade, o que fazia a empresa canadense era barganhar o apoio do governo brasileiro, que, em consonância com aquela política de atração de capitais para a ocupação da região, escala a CVRD para representá-lo no negócio. Além do investimento direto realizado pela CVRD, a Alcan contou com o aparato estatal, o que implicou apoio fiscal e creditício - 44\% dos US\$ 300 milhões necessários, na época, à implantação do projeto (VIVACQUIA, 1981, p. 25). Naquele momento (1975), a CVRD passou a ser a maior acionista da MRN, associada a outras empresas, todas grandes consumidoras de bauxita, à frente delas as multinacionais Alcan, Billiton, Norsk Hydro e a nacional CBA, do grupo de Antônio Ermírio de Moraes.

Garantidos os mecanismos de financiamento, iniciaram-se as obras que viabilizariam a implantação da estrutura necessária à extração, ao beneficiamento e ao transporte da bauxita por uma ferrovia de $30 \mathrm{~km}$ até o porto, onde seria embarcada em navios graneleiros, para ser transportada por via fluvial por quase mil quilômetros antes de ganhar o Atlântico. De tal forma, em agosto de 1979, a MRN efetuou o seu primeiro embarque para a Alcan, no Canadá. Desde essa data, a empresa 
tem ampliado a sua capacidade instalada e sua produção (Figura 2C). Conta hoje com capacidade instalada superior a 16,5 milhões de toneladas/ano, o que representa, segundo a empresa, investimentos que ultrapassam um bilhão de dólares.

Merece citação também o fato de que, durante esse período, uma das principais concorrentes da Alcan, a Aluminium Company of America (ALCOA), que também era titular de direitos de lavra de bauxita de outras jazidas na região do rio Trombetas, utilizou-se de tais direitos como elemento de negociação para que pudesse ingressar como sócia na MRN. A Alcoa insinuava que, caso viesse a extrair a bauxita de suas reservas, ampliaria a oferta no mercado mundial, tornando-a bastante superior à capacidade de assimilação pelas plantas industriais então instaladas. Uma manobra bem-sucedida, que garantiu à Alcoa, a partir de 1992, a condição de uma das empresas controladoras da MRN.

2.1.2 As ações voltadas para a industrialização regional da bauxita do Trombetas

O Governo Federal, para valorizar as reservas de bauxita do Trombetas, não se limitou somente a viabilizar sua extração; elaborou também estratégias para realizar a sua transformação em alumina e alumínio primário na própria região. Para isso, seria necessária a instalação de indústrias para a produção da alumina e a edificação de indústrias metalúrgicas para a produção do alumínio, o que, por sua vez, requeria a disponibilidade de enorme quantidade de energia elétrica.

Para tanto, o Governo Federal promoveu negociações com o intuito de formar uma joint venture (um tipo especial de associação comercial) entre a CVRD e empresas japonesas para a produção de alumina e de alumínio. Além disso, criou, em 1973, a Centrais Elétricas do Norte do Brasil S.A. (ELETRONORTE), com a finalidade de viabilizar a implantação de usinas capazes de aproveitar o potencial hidrelétrico da região, tarefa indispensável para a transformação industrial da alumina em alumínio primário. Tanto que, logo após a sua criação, a Eletronorte assumiu a coordenação da construção da Usina Hidrelétrica de Tucuruí (Figura 1).

Formou-se, em 1973, um comitê composto por empresas japonesas e a CVRD, para estudar a viabilidade da produção do alumínio primário na região (CVRD; LMSA, 1974, p. 1). Em 1975, os parceiros japoneses apontaram a inviabilidade dos negócios, especialmente devido aos elevados custos referentes à participação na construção da Usina Hidrelétrica de Tucuruí e na montagem da infra-estrutura para dar suporte aos projetos. 
Com o aguçamento da crise econômica em âmbito nacional, a relevância de projetos como os que envolveriam a produção do alumínio passa a depender de sua capacidade de gerar rapidamente divisas para contrabalançarem o acelerado crescimento do serviço da dívida externa. Naquele contexto, o Governo Federal, para manter os capitais japoneses como partícipes dos projetos voltados para a produção da alumina e do alumínio, no processo de negociações, eximiu os parceiros da responsabilidade de participação na edificação da usina para a geração de energia elétrica. Assumiu, portanto, os custos referentes à construção da Usina Hidrelétrica de Tucuruí - à época orçada em US\$ 2,1 bilhões e cujos custos finais foram triplicados, segundo as estimativas mais modestas -, como também os encargos relativos à linha de transmissão de energia da hidrelétrica até as instalações industriais em Barcarena, a infra-estrutura urbana e portuária necessária aos empreendimentos, materializada na Vila dos Cabanos e no Terminal Portuário de Vila do Conde.

Consolidou-se em tais bases, em 1978, a Alumínio Brasileiro S.A. (ALBRAS), uma joint venture criada como associação entre a CVRD e a Nippon Amazon Aluminum Corporation (NAAC), um consórcio de empresas japonesas que participou com 49\% do empreendimento, cabendo o restante à CVRD. Para a produção da alumina, criou-se a Alumina do Norte do Brasil S.A. (ALUNORTE).

\subsection{PGC: a concentração espacial da política de incentivos fiscais e creditícios}

O governo, ao assumir a responsabilidade de obras de infra-estrutura de tal porte, enfrentou problemas para financiá-las, pois a crise econômica que marcou a economia nacional no início dos anos 80 refletiu diretamente no montante de recursos que eram transferidos ao Polamazônia, que passaram a ser significativamente reduzidos. Essa redução e o momento conjuntural, no qual o Governo Federal tinha necessidade de agilizar a instalação e o início da operação dos projetos mínero-metalúrgicos, foram os fatores fundamentais para a criação, em 1980, do Programa Grande Carajás (PGC). Uma tentativa de o governo coordenar a execução, de forma mais ágil, de projetos já existentes na área (especialmente o Projeto Ferro Carajás, a Albras, a Alunorte, a Alumar e a Usina de Tucuruí) e de concentrar ainda mais os impactos das políticas estatais de incentivos fiscais para a região. O PGC passou, então, a receber os aportes mais expressivos de fundos públicos destinados a todo o Polamazônia (SILVA, 1982, p. 51), a contar com um sistema especial de financiamento estatal, a envolver negociações de créditos com sistema financeiro internacional, além de criar um sistema adicional de isenções fiscais. 
O PGC foi a expressão de dinâmicas complexas, que abrangiam tanto parte de estratégias do Governo Federal, quanto de dinâmicas mundiais que envolviam um processo de reestruturação locacional da indústria do alumínio primário em âmbito mundial. Era, portanto, um programa que trazia em seu bojo uma grande diversidade de interesses, entre eles os dos governos militares e de grupos transnacionais, aos quais se agregaram os da CVRD, que buscava consolidar na região um ambiente socioeconômico que resguardasse seus investimentos e maximizasse a utilização da infra-estrutura por ela criada.

\subsubsection{A implantação de fábricas de alumínio na região}

É assim que, tendo em vista o PGC, implantaram-se na região empresas voltadas para a produção de alumina e alumínio primário. A Albras instalou-se no município paraense de Barcarena (Figura 1). Nas negociações das condições de sua instalação, o Governo Federal concedeu à empresa subsídio no valor da energia elétrica por ela consumida. Vigorando de 1984 a junho de 2004, tal política tarifária, segundo a Eletronorte, significou subsídio superior a US\$ 1 bilhão.

A Albras foi implementada em duas fases. A primeira fase foi inaugurada em 1985; em 1991 completou-se a instalação da segunda fase, que possibilitou a elevação da produção a um patamar de 350 mil toneladas/ano de alumínio. Disso resultou um ritmo ascendente de produção de alumínio (Figura 2E), para o que, segundo a empresa, foram realizados investimentos que ultrapassaram US\$ 1,5 bilhão.

Paralelamente às negociações que envolveram a criação da Albras, a transnacional Alcoa iniciou articulações também voltadas para a produção de alumínio na Amazônia oriental brasileira. Das negociações resultou a decisão de instalar a empresa em São Luís, Maranhão (Figura 1), e a formação, sob a coordenação da Alcoa, do Consórcio de Alumínio do Maranhão (ALUMAR), para o qual foi garantida uma série de favores de ordem fiscal e creditícia, além de aporte dado pelo Governo do Estado do Maranhão para a montagem da infra-estrutura necessária ao projeto. A Alumar construiu instalações industriais voltadas tanto para a produção da alumina quanto para a do alumínio primário, estando equipada para produzir até 360 mil toneladas/ano de alumínio. As obras para a sua instalação foram iniciadas em 1980, e sua produção, em 1984, já era comercializada.

A Alumar pôde contar também com uma política de tarifas de energia elétrica amplamente favoráveis à empresa, uma vez que dela, como da Albras, não foi requerido nenhum investimento para a geração de energia, além de lhe ser garantido o suprimento de energia elétrica com preços subsidiados. 
Figura 2: Volume e preços de mercadorias de origem mineral comercializadas na Amazônia oriental - empresas selecionadas.

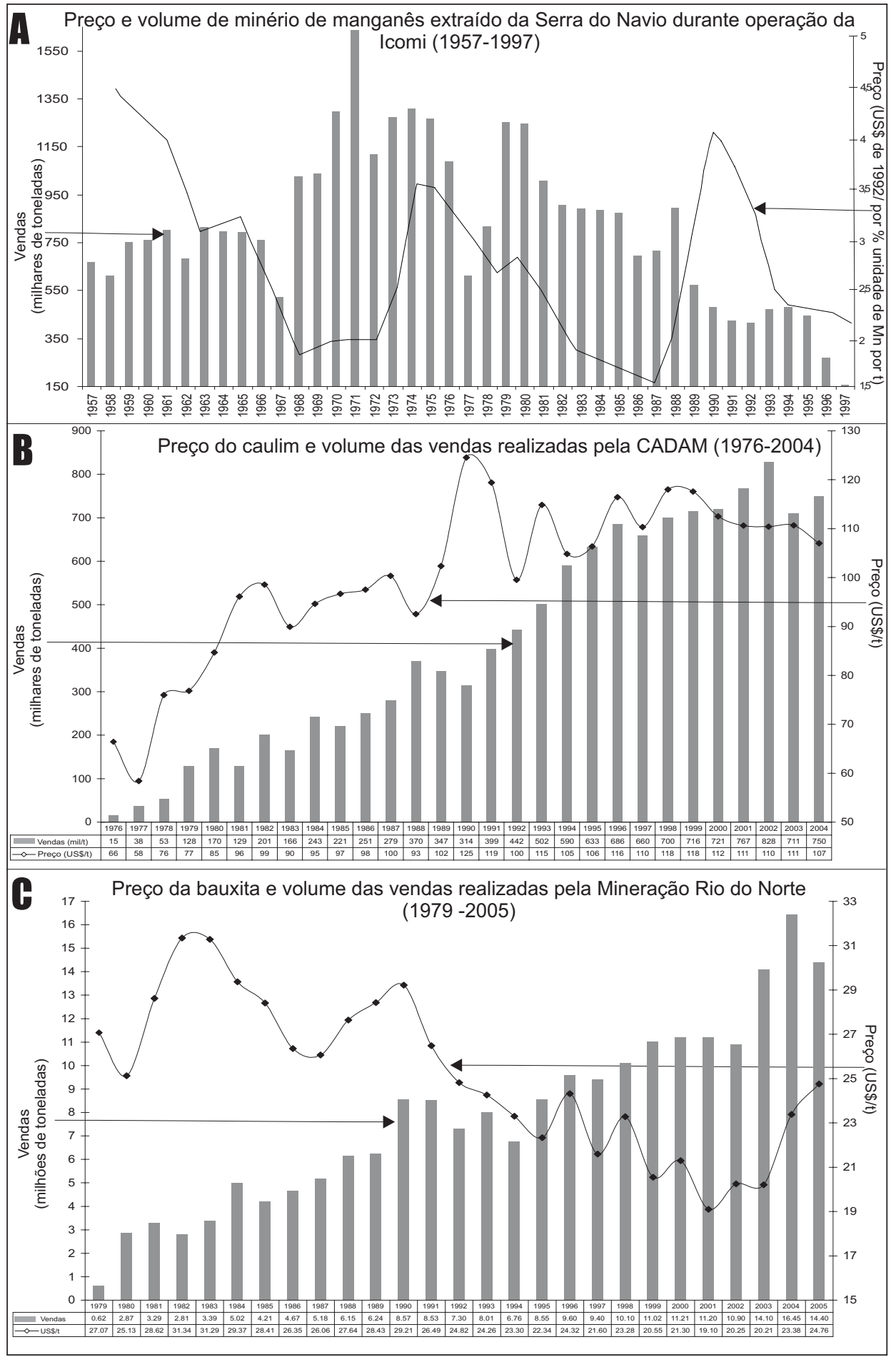




\section{Figura 2 (continuação)}

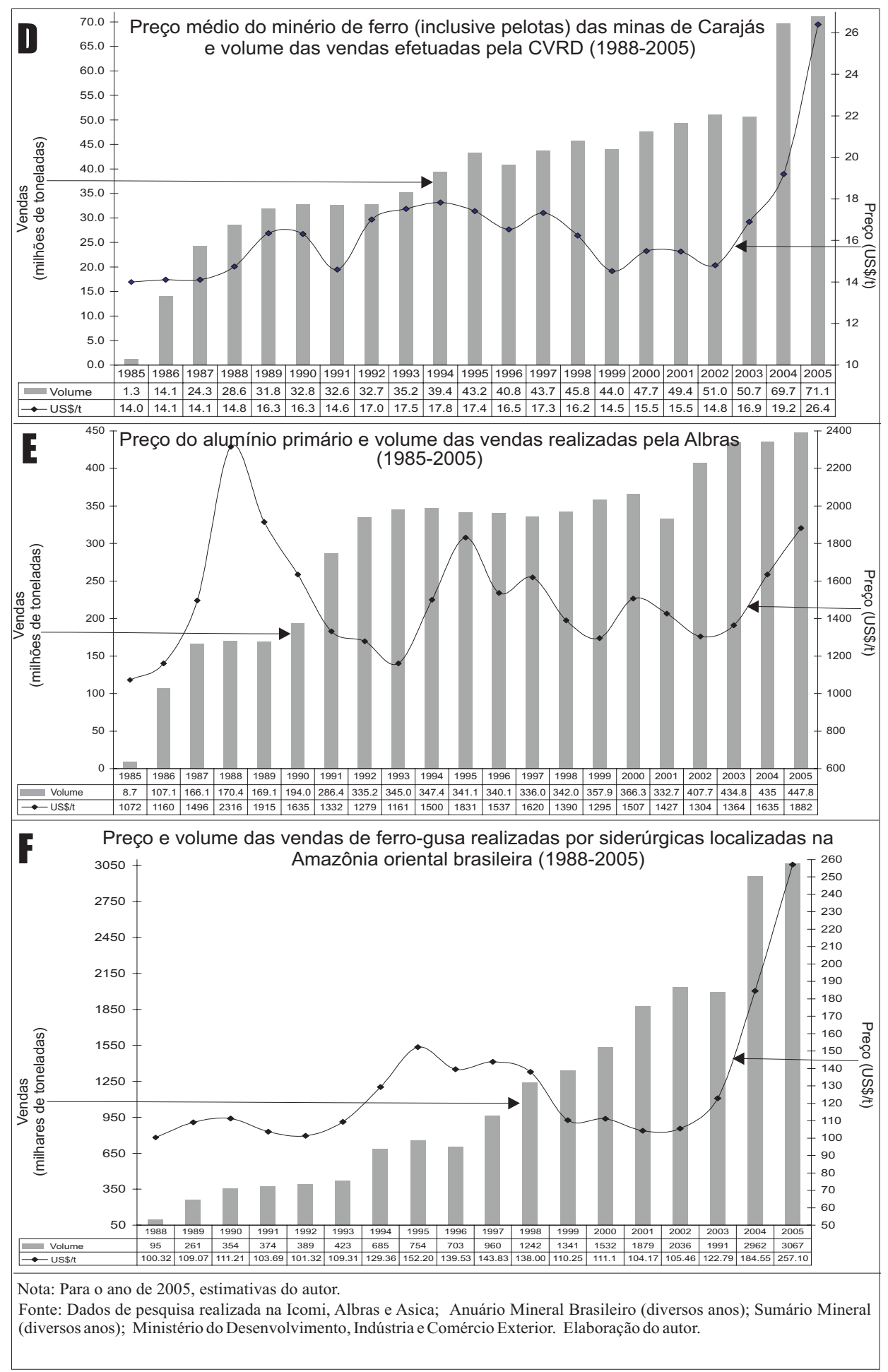


No que se refere à instalação, a Alunorte enfrentou uma série de atrasos e dificuldades. Em 1987, a NAAC, parceira da CVRD no negócio, decidiu não mais investir na Alunorte, e as obras da empresa, que já se processavam em ritmo lento, foram, então, totalmente paralisadas. A conclusão das obras da Alunorte só ocorreu em 1995. Nesse hiato de tempo, o suprimento de alumina para a operação da Albras foi garantido pela importação daquele insumo. Assim, a produção de alumina pela Alunorte só se efetivou uma década após o originalmente planejado.

No processo de negociações que viabilizou a retomada das obras da Alunorte, as empresas envolvidas no ciclo de produção do alumínio no Pará - MRN, Alunorte e Albras - passaram a contar com diversos benefícios fiscais em relação ao Imposto Sobre Circulação de Mercadorias e Serviços (ICMS). A CVRD também conseguiu incorporar novos parceiros ao projeto. Em janeiro de 2000, a Norsk Hydro, uma das sócias da MRN, adquiriu 1/4 das ações da Alunorte, passando também a participar da empresa.

As instalações industriais da Alunorte foram edificadas para produzir 1,55 milhão de toneladas/ano de alumina, quantidade bem superior, portanto, às 700 mil inicialmente projetadas, o que representou, segundo a empresa, um investimento global inicial de US\$ 889 milhões. Em 2003 e em 2004, a capacidade instalada da empresa foi sucessivamente ampliada, atingindo 2,4 milhões de toneladas/ano. As sucessivas ampliações implicaram a alteração do controle acionário: a Vale do Rio Doce Alumínio S.A. (ALUVALE) - controla 57\% das ações e a Norsk Hydro, 34\%. O funcionamento da Alunorte possibilitou a exportação crescente de alumina.

\subsubsection{A exploração das minas da Serra dos Carajás}

Evidentemente também foi no bojo do PGC que se implementou a extração do minério de ferro da Serra dos Carajás, que não ocorreu sem ter sido precedida de um longo processo de negociação, inicialmente envolvendo a criação, em 1970, da Amazônia Mineração S.A., empresa formada a partir de uma associação entre a CVRD e a United States Steel, que, em 1967, havia descoberto as minas. Posteriormente, em 1977, com o fim da associação e a indenização da antiga sócia, a CVRD assume sozinha a condução do Projeto Ferro Carajás.

O minério de ferro é o principal insumo da indústria do aço, o desempenho da siderurgia em âmbito mundial tem estreita relação com o ritmo do crescimento da economia mundial. E as minas de minério de ferro de Carajás estão entre as mais expressivas do mundo (Figura 1). Para a sua exploração montou-se uma gigantesca estrutura que abarca, 
além da company town na Serra dos Carajás, minas, instalações de beneficiamento e um pátio de estocagem, instalações portuárias e a Estrada de Ferro Carajás, cujos 890 quilômetros de extensão ligam a Serra dos Carajás ao terminal marítimo da Ponta da Madeira, na capital do Estado do Maranhão (Figura 1). Esse sistema começou a operar em 1985, inicialmente com uma capacidade instalada de 15 milhões de toneladas/ ano; na segunda fase do empreendimento, essa capacidade saltou para 35 milhões, e atualmente a empresa trabalha com capacidade de 70 milhões de toneladas/ano. De tal modo, a extração de minério de ferro tem sido incessantemente ampliada (Figura 2D). Os investimentos na mina, na ferrovia e no porto, segundo a empresa, já consumiram recursos que ultrapassam US\$ 2,5 bilhões.

No bojo dos investimentos voltados para a extração do minério de ferro de Carajás, ganhou também viabilidade econômica a exploração das jazidas de manganês do Igarapé do Azul, também em Carajás (Figura 1). De forma que, no final de 1985, a CVRD iniciou a lavra daquela mina, que contava, na sua primeira fase, com uma usina de beneficiamento do minério com capacidade para processar até 700 mil toneladas/ano. Em 1991 a CVRD ampliou a capacidade de produção de manganês, elevando-a para 1,7 milhão de toneladas/ano. Na mina do Azul, depois de beneficiado, o minério é transportado por meio de caminhões por $34 \mathrm{~km}$ de estrada até o pátio da Estrada de Ferro Carajás, onde é embarcado. Apesar das ampliações da capacidade de beneficiamento de minério, a produção do manganês do Azul apresentou oscilações, e em 1999 a sua lavra chegou a ser suspensa.

Os lucros auferidos pela CVRD, tanto os decorrentes da exploração do minério de ferro, quanto os vinculados à comercialização do manganês, foram dispensados pelo PGC do pagamento do IR por um período de dez anos e obtiveram posteriormente a prorrogação de tais benefícios tributários.

\subsubsection{Empresas sídero-metalúrgicas impulsionadas pelo PGC}

O PGC também incentivou, na sua área de abrangência, a instalação de empresas que se dedicassem à produção de ferro-gusa, ferroligas, silício metálico e aço, chegando a autorizar a concessão de benefícios para a implantação de 22 empresas sídero-metalúrgicas.

Das empresas dedicadas à produção do ferro-gusa, instalaramse ou iniciaram as obras de seus altos-fornos 15 siderúrgicas. Em Marabá, entraram em operação, no final da década de 80, a Companhia Siderúrgica do Pará (COSIPAR) e a Siderúrgica Marabá S.A. (SIMARA). Mais recentemente, instalaram-se a Siderúrgica Ibérica do Pará S.A. (Ibérica), a Usimar LTDA, a Terra Norte Metais LTDA, a Fer- 
ro-Gusa Carajás (FGC) e a Siderúrgica do Pará S.A. (SIDEPAR). No leste maranhense, no município de Babaceira, instalou-se a Maranhão Gusa S.A. (MARGUSA). A Companhia Siderúrgica Vale do Pindaré (COVAP), a Gusa Nordeste S.A., a Siderúrgica do Maranhão S.A. (SIMASA), a Ferro-Gusa do Maranhão S.A. (FERGUMAR) e a Viena Siderúrgica do Maranhão operam em Açailândia - esta última, operando com quatro altos-fornos, é a maior produtora de ferro-gusa do Brasil. Na cidade de Pindaré Mirim, também no Maranhão, já se encontra em atividade a Companhia Siderúrgica do Maranhão (COSIMA), e a Susa Industrial está instalando seu primeiro forno. A CVRD já anunciou planos de instalar, em sociedade com a NUCOR, uma das maiores siderúrgicas norte-americanas, uma siderúrgica com 4 altos-fornos para produzir ferro-gusa em Marabá (Figura 1).

Para sua instalação, as primeiras empresas siderúrgicas contaram com inúmeros favores estatais. Na composição dos seus capitais, os recursos oriundos do Fundo de Investimento da Amazônia (FINAM) e do Fundo de Investimento do Nordeste (FINOR) foram extremamente relevantes, em alguns casos representam até 75\% dos capitais investidos (MONTEIRO, 1998, p. 94).

Como todas produzem tão-somente ferro-gusa, são denominadas produtoras independentes. Diferentemente, portanto, das siderúrgicas chamadas de integradas, que, controlando todas as etapas da produção, desde o minério de ferro até o produto final, fabricam produtos de aço, como tarugos, placas, chapas, bobinas, vergalhões e cabos. O ferro-gusa - uma forma intermediária pela qual quase todos os compostos ferríferos têm de passar, antes de serem transformados em aço - requer para sua produção, além do minério de ferro, grande quantidade de carvão para atuar como redutor. A siderurgia regional utiliza o carvão vegetal, insumo muito importante e que pode representar até $40 \%$ dos custos da produção do ferro-gusa (MONTEIRO, 1998, p. 133). Esse carvão vegetal, oriundo quase exclusivamente da floresta primária, é proveniente de lenha de desmatamentos ou é produzido com base em resíduos de madeira beneficiada por serrarias, que também recorrem à floresta nativa.

Mesmo levando em conta a defasagem considerável entre a projeção inicial do PGC e os projetos que se efetivariam, a entrada em operação dessas indústrias possibilitou uma produção crescente de ferrogusa, que começa a mostrar-se significativa (Figura 2F). Com a instalação de novos altos-fornos por empresas já em operação e a possível instalação de novas siderúrgicas, a produção, que, em 2004, foi de 2,96 milhões de toneladas, deverá ser ampliada. Isso implica também o consumo de 
carvão vegetal, nem um pouco desprezível - aproximadamente 3 milhões de toneladas de carvão, uma demanda que amplia a pressão pelo desmatamento de novas áreas. Quanto ao minério de ferro, a demanda originada por essas siderúrgicas é residual, se comparada ao montante anualmente extraído da Serra dos Carajás. Em 2004, por exemplo, as guseiras localizadas na Amazônia oriental brasileira consumiram 4,6 milhões de toneladas, volume de minério que equivale a 6,6\% do total extraído de Carajás naquele ano.

A Camargo Corrêa Metais (CCM) também foi outra empresa cuja previsão de operação pelo PGC se concretizou. A formação do capital da empresa vinculou-se a incentivos fiscais concedidos, no âmbito do PGC, à Construtora Camargo Corrêa, que participou da construção da Hidrelétrica de Tucuruí. A CCM dedica-se à produção de silício metálico e localiza-se a $5 \mathrm{~km}$ da Usina de Tucuruí, no município paraense de Breu Branco. Entrou em operação no segundo semestre de 1988, atualmente conta com quatro fornos e possui uma capacidade de produção de 36 mil toneladas/ano, que nunca foi alcançada.

Em seu processo produtivo, além do quartzito, a CCM utiliza outros insumos, como o carvão vegetal, o cavaco de madeira e a energia elétrica, esta proveniente da Usina de Tucuruí e transmitida por uma linha de propriedade da CCM. Já para garantir o suprimento do carvão e do cavaco de madeira, a CCM recorre à madeira oriunda da mata primária, além de desenvolver projeto de reflorestamento. Os insumos minerais destinados à metalurgia do silício metálico vêm de diversas jazidas de quartzito, algumas da própria empresa e outras cuja titularidade é da CVRD.

\section{O FIM DA CENTRALIZAÇÃO AUTORITÁRIA}

O poder de centralização autoritária dos governos militares foi sendo corroído no decorrer da década de 80, um processo que teve como corolário o fim dos governos militares, em 1985, e a promulgação da Constituição de 1988. Alteraram-se, assim, importantes mecanismos de mediação entre os interesses de diversos grupos no interior da sociedade, metamorfosearam-se as relações entre Estados e União, um processo que teve efeitos diversos e significativos sobre a condução da política de valorização dos recursos minerais da Amazônia. O PGC, que já vinha sofrendo questionamentos por parte da sociedade, é esvaziado para, em seguida, ser extinto. A SUDAM e diversos outros órgãos da burocracia federal que tiveram papel de destaque no aporte estatal para a implantação regional de empresas mínero-metalúrgicas têm a sua 
importância reduzida e parte do sistema de renúncia fiscal que era executado no âmbito do PGC foi extinta. É bem verdade que instrumentos importantes na consecução das políticas dos militares, como o FINAM ou como a concessão de redução de IR, foram mantidos e passaram a ser coordenados unicamente pela SUDAM, até a sua extinção em fevereiro de 2001.

Concomitantemente às mudanças na organização do Estado brasileiro, ganha importância a preocupação social com as questões ambientais. A "proteção ao meio ambiente" passa inclusive a integrar o quadro de garantias fundamentais da Constituição, ao que se agregam outras exigências constitucionais, tais como a obrigatoriedade de estudo prévio de impacto ambiental, a necessidade do licenciamento ambiental prévio, além da obrigação da recomposição do meio ambiente degradado pela mineração, o que explica, por exemplo, a enorme repercussão que tiveram as denúncias da degradação ambiental decorrente da deposição, no lago Batata, da lama vermelha resultante do beneficiamento primário da bauxita pela MRN - uma prática que àquela altura já perdurava há uma década e que já havia coberto um quinto do lago. A preocupação com o meio ambiente também ajuda a explicar os investimentos feitos pela MRN - que, segundo a empresa, atingiram US\$ 70 milhões - para reestruturar o esquema de beneficiamento da bauxita, de maneira que, a partir de 1989, não mais fossem lançados no lago Batata os resíduos do beneficiamento da bauxita, e para iniciar a recuperação do lago.

Desenhou-se, assim, no final da década de 80, um cenário no qual as políticas públicas destinadas à valorização dos recursos minerais da região são marcadas pela substancial redução da capacidade do Governo Federal de coordenar, centralizar e direcionar grandes financiamentos ou mesmo investimentos diretos em empresas mínero-metalúrgicas e em infra-estrutura de suporte a elas. O que, entrementes, não implicou, necessariamente, a extinção das políticas de renúncia fiscal ou de financiamentos, oriundos de fundos públicos, destinados a empresas mínero-metalúrgicas.

\subsection{Novas empresas e novos impactos ambientais}

Foi naquele ambiente que surgiu a Companhia de Ferroligas do Amapá (CFA), empresa criada pela Caemi tanto para a exploração do minério de cromo - cromita -, quanto para a produção de ligas metálicas. A CFA iniciou em 1988 a exploração da jazida às proximidades da localidade de Santa Maria do Vila Nova, no município de Mazagão, Amapá (Figura 1). Para tanto, além das instalações da mina, foram construídas uma usina de beneficiamento e uma planta para concentração do miné- 
rio. A cromita, depois de concentrada, é transportada, por via rodoviária, por $38 \mathrm{~km}$, até a Vila de Cupixi, de onde passa a ser escoada pela Estrada de Ferro do Amapá, em direção ao porto de Santana, onde é exportada, sendo utilizada como insumo na indústria siderúrgica, para a produção de aço inoxidável.

Já no que tange às atividades metalúrgicas da CFA - produção de ligas metálicas -, elas estiveram estreitamente relacionadas ao início da utilização de novos equipamentos industriais pela Icomi. Com a paralisação de sua usina de pelotização, em 1985, a empresa passou a utilizar-se de uma usina de sinterização para aglomerar a fração fina do minério de manganês, dando origem a um produto denominado sínter de manganês. A usina entrou em operação em 1989 e passou a beneficiar minério de manganês de baixa granulometria extraído na Serra do Navio. Parte do sínter de manganês era exportado e outra parte tinha como destino os fornos da CFA, onde era convertido em ligas de manganês.

Portanto, quase concomitantemente ao desenvolvimento da usina de sinterização pela Icomi, a CFA implantou um forno elétrico para a transformação industrial de minérios de manganês e de cromo. O projeto previa uma flexibilidade na produção da empresa, de forma a produzir ligas tanto de ferro-manganês quanto de ferro-cromo. Dos recursos necessários para a montagem da empresa, 50\% foram oriundos do FINAM (PLANASA, 1987, p. 116). A produção de ligas iniciou-se em 1990. Contrariando as perspectivas iniciais, a empresa não conseguiu produzir ligas de ferro-cromo, produzindo apenas ligas de ferro-manganês. Em 1996, a CFA encerrou suas atividades na área da siderurgia, atribuindo a a inviabilidade do empreendimento ao alto custo da energia elétrica e à redução do preço das ligas no mercado mundial.

Como se apontou, em 1997 a Icomi encerrou a exploração das minas de manganês da Serra do Navio e deu prosseguimento à transferência de outros dos seus negócios no Amapá. Entretanto, durante as negociações que envolviam a aquisição, pela empresa Champion Papel e Celulose, do domínio útil da área industrial e portuária da Icomi em Santana (Figura 1), a Champion solicitou a realização de auditoria ambiental na área. A investigação constatou a contaminação das águas superficiais e de lençóis freáticos por arsênio e manganês. O dano ambiental decorreu da deposição inadequada de resíduos originados nos processos tanto de pelotização quanto de sinterização da fração fina do minério de manganês. A constatação era gravíssima, pois a contaminação da população humana por arsênico pode ocasionar câncer, problemas neurológicos, cardíacos e renais. A existência da possi- 
bilidade de exposição ao arsênio de populações residentes no entorno das instalações portuárias da Icomi ensejou a realização de investigações mais detalhadas. Esses estudos constataram a existência de teores de arsênio bastante elevados na área portuária da Icomi (LIMA, 2002); todavia, as pesquisas também indicaram que não houve prejuízos à saúde das populações em decorrência da presença de níveis elevados de arsênio na área portuária da empresa (MIRANDA, 2002).

No que se refere às atividades de mineração executadas pela CFA, a Icomi arrendou os direitos de lavra à Mineração Vila Nova (MVN), subsidiária de um dos maiores produtores mundiais de aço inoxidável, o grupo norueguês Elkem. Em 1998, a Mineração Vila Nova adquire esses direitos e dá prosseguimento à exploração do minério, atingindo, em 2000, produção superior a 142 mil toneladas de cromita, para sofrer uma redução significativa em 2001. Em janeiro de 2002, a Elkem decidiu encerrar a produção de ligas de ferro-cromo na Europa. Como o principal papel da MVN era o suprimento daquela empresa, a Elkem também decidiu paralisar definitivamente as atividades de mineração no Amapá.

Dada a decisão de retirar-se do mercado de cromo, em dezembro de 2002, a Elkem transferiu a propriedade da MVN para a Fasa Participações S. A. Assim, o retorno das atividades de mineração ocorreu em meados 2003, em escala menor e já sob o controle de novo proprietário.

\subsection{A expansão da exploração industrial do ouro nos anos 80 e 90}

Nos anos 80, houve grande elevação no preço do ouro no mercado mundial. Isso impulsionou a expansão da exploração industrial do ouro na região, uma dinâmica que por vezes implicou choques entre empresas mineradoras e garimpeiros. Merecem nota os conflitos que envolveram a Oca Mineração e os ocupantes do garimpo do Itatá, localizado no município de Senador José Porfírio, Pará, em local conhecido como Volta Grande do Xingu. Lá a empresa buscou estabelecer a produção industrial de ouro. Entretanto o litígio que envolveu a definição da propriedade da área ampliou a tensão entre a mineradora e os garimpeiros, que, em 1986, ocuparam a empresa, de forma que a instalação da mineração industrial não prosperou.

A tensão entre garimpeiros e a empresa mineradora também marcou a instalação da Mineração Novo Astro (MNA), que, em 1982, adquiriu direitos minerários de áreas de garimpagem conhecidas como garimpo Mutun e Lourenço, no município de Calçoene, Amapá, a cerca 
de 400 quilômetros de Macapá (Figura 1), local cuja atividade garimpeira data do final do século XIX. A partir daí, a empresa iniciou um processo de desocupação das áreas, expulsando cerca de 1.500 garimpeiros e implantando uma segurança patrimonial para a manutenção das áreas (PINTO et al., 1999, p. 30), que, segundo os garimpeiros, contava com armamento pesado e agia com extremada violência. Garantida a posse da área, a MNA edificou suas instalações e, em 1984, já extraía ouro. A relação entre os garimpeiros e a MNA sempre se manteve muito tensa, chegando a ocorrer, em setembro de 1986, a ocupação das instalações da empresa por garimpeiros.

Segundo a empresa, US\$ 56,2 milhões foram requeridos para estruturar a mineração, recursos destinados a instalações de beneficiamento do minério, aos equipamentos de mineração e à edificação do "Núcleo Residencial do Lataia", com capacidade para abrigar 800 pessoas, que dispunha inclusive de um hospital. Para tanto, a empresa contou com financiamento do BNDES, além de ter sido beneficiada pela Sudam com isenção de IR pelo prazo de 10 anos (MNA, 1988, p. 1).

Em 1995, a MNA encerrou suas atividades, tendo extraído 20 t de ouro. Apesar das muitas evidências da enorme degradação ambiental ainda presente na área da empresa, ela obteve da Coordenadoria Especial de Meio Ambiente do Amapá (CEMA) a aprovação de seu relatório final de recuperação das áreas degradadas. A empresa empenhou-se então em transferir seus direitos minerários para a recém-criada Cooperativa de Mineração dos Garimpeiros do Lourenço (COOGAL). O que se encontra, hoje, na área onde funcionou por mais de uma década a MNA é um quadro de degradação ambiental e social.

Em meados da década de 80, duas novas empresas passaram a dedicar-se à exploração do ouro no Amapá, e teve também início a extração do ouro da mina do igarapé Bahia, no Pará, cuja operação permitiu que a exploração industrial suplantasse, na região, o volume de ouro procedente de garimpos.

Uma dessas empresas foi a Mineração Yukio Yoshidome S.A. (MYYSA), que se instalou em um local denominado Labourrie, a $3 \mathrm{~km}$ da Vila de Lourenço (Figura 1), às proximidades das instalações da MNA. A MYYSA entrou em funcionamento em 1985, realizando a lavra subterrânea do minério. Apesar de descrever, em seu plano de reabilitação ambiental, o processo de beneficiamento como ambientalmente prudente (PROMINER, 1989, p. 6), a empresa, na verdade, nunca utilizou tal processo. Para a exploração do ouro, recorria ao mercúrio sem nenhuma prudência ecológica. 
A MYYSA durante suas atividades retirou tão-somente 1,3 t de ouro das 5 t previstas nas pesquisas geológicas. Em 1992, ela encerrou suas atividades, envolta em vultosas demandas trabalhistas. Em 1997, houve uma tentativa, sem êxito, por parte da associação dos funcionários, para retomar a operação da mina. As áreas degradadas pela mineração não foram recuperadas e, atualmente, encontram-se sob a administração de um antigo funcionário, que dirige um pequeno garimpo na antiga cava da mina e protege a área contra ocupações.

Outra empresa dedicada à exploração industrial de ouro a entrar em operação naquele período foi a Mineração Água Boa, que iniciou em 1992 a exploração da mina localizada no município de Mazagão, Amapá, às margens do igarapé Santa Maria, a $3 \mathrm{~km}$ ao sul de uma localidade conhecida como Gaivota (Figura 1). A empresa funcionou por 5 anos e, quando encerrou as atividades, não recuperou as áreas degradadas, deixando duas enormes cavas em cada uma das margens do igarapé Santa Maria, uma delas com aproximadamente $1 \mathrm{~km}$ de extensão, 200 metros de comprimento e 60 metros de profundidade. As duas cavas são hoje ocupadas por garimpeiros.

$\mathrm{Na}$ década de 90, a produção industrial de ouro passou a ser regionalmente incrementada pela exploração das minas do igarapé Bahia pela CVRD. A jazida foi descoberta em 1985, durante os trabalhos de prospecção para cobre. A nova mina situa-se nas áreas da CVRD, no Sudeste paraense, atualmente município de Parauapebas. Em 1990, foi iniciada a produção de ouro na mina do igarapé Bahia, e, em 1995, a produção da mina ultrapassou a produção anual de 10 mil toneladas de ouro.

Segundo a CVRD, a extração de ouro do igarapé Bahia implicou investimentos de US\$ 130 milhões, beneficiados com o incentivo fiscal aprovado pela Sudam, o que possibilitou à CVRD reduzir em 50\% o IR devido sobre os lucros auferidos em decorrência da exploração dessa mina. Em 2002, a lavra de ouro foi encerrada.

\subsection{Reformas no Estado e novas dinâmicas para a implantação de empresas}

Com a eleição de Fernando Collor para a presidência da República e, posteriormente, com a de Fernando Henrique Cardoso, consolidaramse alterações em aspectos relevantes da forma de atuação, do sentido e das funções da intervenção estatal - mudanças derivadas, sobretudo, de dinâmicas mundiais que impuseram novos modelos de desenvolvimento para economias nacionais. Ganha força crescente na agenda do governo brasileiro a necessidade de "liberalização da economia", de re- 
alização de mudanças capazes de "ampliar e adaptar a competitividade das economias nacionais" frente ao "imperativo" de um mundo cada vez mais "globalizado" (BRASIL, 1997a, p. 13). Em tais ajustes inclui-se a diminuição de barreiras alfandegárias, a redução da tributação incidente sobre exportações, a redução da participação estatal na economia, por via, por exemplo, de privatizações de empresas estatais, como veio a acontecer com a CVRD.

Foi naquele contexto histórico que se aprovou, em 1995, a Emenda Constitucional $n .^{\circ}$ 6, que retirou o impedimento, até então existente, à participação majoritária do capital estrangeiro nos capitais de empresas de mineração. Essa mudança permitiu, por exemplo, à norueguesa Elkem adquirir os direitos de lavra da cromita no Amapá e passar, como já se mencionou, a dirigir a atividade por meio de sua subsidiária, a Mineração Vila Nova. É o cenário também no qual, em 1996, o Governo Federal, sob a justificativa de tornar mais competitivos os produtos nacionais, por meio da Lei Complementar n. ${ }^{\circ}$ 87/96, que ficou conhecida como Lei Kandir, passou a isentar de recolhimento do ICMS os produtos primários ou semibeneficiados destinados à exportação, entre eles minerais e produtos da siderurgia básica. Houve igualmente uma mudança na legislação federal relacionada aos incentivos fiscais vinculados ao IR: o Governo Federal extinguiu, a partir de 1997, a possibilidade de novas concessões de isenção de IR e, no caso de redução daquele imposto, estabeleceu percentuais menores dos que até então podiam ser concedidos; manteve, entretanto, os benefícios já concedidos.

Alteram-se também as concepções das formas de se impulsionar o desenvolvimento regional. Nas décadas passadas, de uma maneira ou de outra, a noção predominante era a de que a modernização da região vinculava-se ao estabelecimento de pólos de desenvolvimento; essa noção perdeu espaço para a concepção segundo a qual o fundamental para o desenvolvimento regional é o estabelecimento de "eixos estruturadores de integração nacional e internacional" (BRASIL, 1997b, p. 17), concebidos como alternativa para articular diferentes regiões entre si. Esses eixos assumem a forma concreta de vias de transporte de longa distância que possibilitariam, segundo o Governo Federal, o "acesso a mercados e a melhorar a capacidade competitiva dos sistemas econômicos regionais" (BRASIL, 1997b, p. 17), sendo a Amazônia oriental brasileira cortada por dois desses eixos. Em relação à mínero-metalurgia, o discurso dos planejadores do Governo Federal passa a indicar que ela poderia contribuir para o desenvolvimento regional, a partir da "geração de cadeias de integração produtiva" das atividades já existentes (BRASIL, 1997a, p. 106). 
A configuração dessas posturas pode ser percebida na estruturação de novas empresas mínero-metalúrgicas na região. Tome-se, por exemplo, o caso da CVRD, que, ainda na condição de empresa estatal, detinha os direitos de lavra de jazidas de caulim localizadas perto do rio Capim, no município de Ipixuna, Pará. Tendo interesse no início da extração do minério, o Governo Federal impôs uma condição à CVRD: a empresa não poderia dirigir o empreendimento, mesmo sendo titular dos direitos de lavra e possuidora de recursos para a formação da nova empresa. Assim surgiu, no início da década de 90, a Rio Capim Química S.A. - posteriormente denominada Pará Pigmentos S.A. (PPSA) -, cuja maior acionista era a Cadam, cabendo à CVRD a condição de acionista minoritária.

Em 1996, a PPSA iniciou a lavra do caulim. Depois de lavrado, o caulim é transportado para a usina de tratamento, de onde, já beneficiado, é bombeado, na forma de polpa, por um mineroduto com $180 \mathrm{~km}$ de extensão, até atingir as instalações da empresa em Barcarena, onde é secado e embarcado em um terminal portuário da própria empresa (Figura 1).

Em 1998, a CVRD, já privatizada, comprou a participação da Caemi, assumindo o controle acionário da PPSA. Em face das condições de mercado extremamente favoráveis ao produto, a empresa pretende alcançar o volume de 1 milhão de toneladas/ano, limite para o qual foi projetado o mineroduto.

No município de Ipixuna, também se instalou a Imerys Rio Capim Caulim (Figura 1), uma empresa inicialmente denominada Rio Capim Caulim S.A.. Pertencente ao Grupo Mendes Júnior, foi adquirida pela multinacional Imerys, uma das maiores produtoras mundiais de caulim. Essa aquisição só foi possível em virtude da já citada mudança na legislação brasileira, que passou a permitir que empresas mineradoras fossem controladas por capitais forâneos. As obras civis da Imerys Rio Capim Caulim (IRCC) tiveram início em 1994 e, em 1996, era efetivado o primeiro embarque de caulim. A concepção da exploração do caulim adotada pela IRCC é diferente da que seguiu a PPSA, uma vez que a subsidiária da Imerys optou por concentrar as principais instalações de beneficiamento do caulim em Barcarena, enquanto a PPSA concentrou-as nas proximidades das minas, em Ipixuna (Figura 1). Inicialmente o minério explorado pela Imerys era transportado por via fluvial; atualmente o transporte é feito por um mineroduto de $130 \mathrm{~km}$, que segue, em parte significativa de sua extensão, o mesmo traçado do pertencente à PPSA - até Barcarena, onde se localizam as instalações da empresa. Lá o minério é submetido a processos de beneficiamento, para só depois ser comercializado (Figura 1).

Como as demais produtoras de caulim instaladas na região, a Imerys também pretende expandir sua produção e comercializar $1 \mathrm{mi}-$ 
lhão de toneladas de caulim por ano. Foi essa perspectiva de ampliação que condicionou o abandono do transporte fluvial do minério e a construção do mineroduto anteriormente citado.

\subsection{As tensões no governo Lula e a manutenção de lógicas de valorização de minerais na Amazônia}

O documento que, em tese, deve dirigir a Política Nacional de Desenvolvimento Regional do governo do presidente Lula da Silva indica que um dos principais objetivos das ações do Governo Federal, no que tange às políticas de desenvolvimento regional, é "explorar, com afinco, os potenciais endógenos da magnificamente diversa base regional de desenvolvimento, em conformidade com os fundamentos sociais atuais de uma produção mais diversificada e sofisticada, mais portadora de valores sociais regionalmente constituídos" (BRASIL, 2003a, p. 12). Propoem-se, nestes termos, apoiar como mecanismo de desenvolvimento regional, aqueles agentes que têm a sua competitividade baseada em vantagens competitivas, e não, impulsionar o desenvolvimento regional, apoiando aqueles agentes cuja estratégia de competitividade funda-se na utilização tão-somente de vantagens comparativas decorrentes dos baixos custos do acesso aos recursos naturais. Esse mesmo fundamento, em linhas gerais, também está presente no documento Plano Amazônia Sustentável (BRASIL, 2004, p. 60).

Todavia, no que concerne às ações concretas, a atuação do Governo Federal para a Amazônia não tem se pautado, fundamentalmente, pelo que está exposto naqueles documentos, pois uma análise das ações do Governo para a Amazônia indica que a lógica de sua atuação vinculase, em grande medida, a uma estratégia expressa no documento Plano Plurianual 2004-2007 (BRASIL, 2003b), que prevê ações que reforçam as lógicas, vigentes nos períodos anteriores, de relacionamento entre o poder público e as empresas responsáveis pela mercantilização de bens de origem mineral.

O Plano Plurianual Brasil tem como ponto de referência uma análise segundo a qual o desenvolvimento econômico do país está bloqueado pela existência de restrições que produzem vulnerabilidade externa e interna. A primeira delas seria a baixa capacidade de geração de divisas na balança comercial e de atração de capitais produtivos. Essa reduzida capacidade de geração de divisas tem tornado o Brasil altamente dependente de capitais para fechar suas contas com o resto do mundo. Nesses termos, a superação da vulnerabilidade externa requer que seja dada máxima prioridade à elevação do saldo da balança comercial, o 
que implica dispensar tratamento privilegiado aos agentes econômicos, como as empresas mínero-metalúrgicas, cujas mercadorias exportadas têm baixíssimo coeficiente de importação, do que deriva um resultado líquido maior nas contas correntes externas.

Essa postura do Governo é manifesta na presença do próprio presidente da República na inauguração da terceira linha de produção da Alunorte, que permitiu o já citado incremento no volume exportado pela empresa de 730 mil toneladas/ano de alumina para 1,4 milhão de toneladas/ ano. Em 2004, tais exportações significaram vendas de US\$ 307 milhões. O presidente da República também se fez presente na inauguração, em 2004, do projeto da CVRD, na região de Carajás, destinado à valorização do minério cobre na mina do Sossego, município de Canaã dos Carajás, Pará projeto que, durante as próximas duas décadas, será responsável pela mercantilização anual de 140 mil toneladas de concentrado de cobre.

A 15 quilômetros da mina de cobre do Sossego, a CVRD deverá construir estruturas aptas a valorizar o níquel de uma jazida conhecida como "Níquel do vermelho", da qual, prevê-se, se extrairão 46 mil toneladas/ano de níquel a partir de 2006. O níquel também deverá ser extraído nas serras Onça e do Puma, localizadas no município de Ourilândia do Norte, Pará. Trata-se de um investimento realizado pela Mineração Onça Puma (MOP), uma subsidiária da canadense Canico Resource Corporation, e deverá comercializar 53 mil toneladas/ano de níquel a partir de abril de 2008 (Figura 1).

Nesse cenário de expansão de investimentos destinados à valorização e à exportação de bens minerais na Amazônia, é que no, município de Ferreira Gomes, Estado do Amapá, a empresa Sólida Mineração já iniciou a instalação de equipamentos para a extração de minério de ferro. A capacidade de lavra é estimada em 1,5 milhão de toneladas/ano, e sua comercialização está prevista para iniciar-se em 2005 (Figura 1). Parte do minério de ferro, 300 mil toneladas/ano, será destinada à produção de ferro-gusa no Amapá pela própria empresa, e o restante será destinado ao mercado externo.

Aos empreendimentos mencionados acima, soma-se a valorização de bauxita, pela CVRD. Trata-se de jazidas localizadas no município paraense de Paragominas (Figura 1). Na fase inicial do negócio, serão explorados 4,5 milhões de toneladas/ano; posteriormente, esse volume será expandido para 9 milhões de toneladas/ano. O minério destina-se a suprir o aumento da demanda da Alunorte, que pretende expandir sua capacidade produtiva para 4,2 milhões de toneladas/ano de alumina. O transporte do minério será efetivado por um mineroduto de $247 \mathrm{~km}$, que deverá entrar em operação em junho de 2006. 
A valorização da bauxita na Amazônia oriental brasileira será ainda incrementada pela implantação do projeto Juruti, localizado no município de Juruti (Figura 1), no Oeste paraense. Em sua fase inicial, deverão ser mercantilizados 6 milhões de toneladas/ano de bauxita, volume que poderá ser expandido para 10 milhões de toneladas/ano numa segunda etapa. A bauxita será destinada à refinaria da Alumar em São Luís, Maranhão. A previsão é de que em 2008 esse minério já estará no mercado.

A política do Governo Federal de priorizar a ampliação de superavits na balança comercial tem efeitos concretos nos processos de desenvolvimento em curso na Amazônia, pois tais prioridades convergem na ação e redundam em práticas que fortalecem agentes econômicos que se valem das vantagens comparativas derivadas do baixo custo, em termos presentes, do uso dos recursos naturais da região, ou seja, da valorização do minério de ferro, de bauxita, de cobre, de alumina, de alumínio, do ferro-gusa, e não no estabelecimento de políticas que sejam capazes de explorar os "potenciais endógenos" e impulsionar "uma produção mais diversificada e sofisticada".

\section{VALORIZAÇÃO DE RECURSOS MINERAIS E DESEN- VOLVIMENTO LOCAL}

Os desdobramentos da mercantilização de recursos minerais na região, apesar de envolverem a produção de mercadorias bastante diversas, valorizadas por empresas que foram instaladas em momentos históricos distintos, guardam importantes e decisivas singularidades e contam com lógicas e características comuns no que tange a repercussões em relação aos processos de desenvolvimento regional. Assim, a análise das dinâmicas gerais derivadas das atividades voltadas para a valorização de minerais da região facilita, sobretudo, a compreensão da limitada capacidade que as empresas têm para impulsionar processos de desenvolvimento local.

Essa incapacidade da mínero-metalurgia para impulsionar dinâmicas de desenvolvimento amplas e socialmente enraizadas tornase mais clara quando se levam em conta as interpretações das trajetórias de inovação tecnológica (DOSI et al., 1988; FREEMAN, 1994) e as novas abordagens da organização institucional e do caráter endógeno de processos de desenvolvimento duradouros (ROMER, 1994; KRUGMAN, 1995; ARTHUR, 2000), que apontam a necessidade de se considerar o papel assumido pelo capital social (COLEMAN, 1990) e pelas 
especificidades sociais, institucionais, culturais e ecológicas - elementos determinantes para se implantar o processo de desenvolvimento local. Trata-se aqui da capacidade de se estabelecer regionalmente vantagens competitivas que seriam decorrentes de uma ambiência historicamente construída (DOSI et al., 1988) e não da simples utilização de vantagens comparativas, cujos pressupostos teóricos derivam de modelos vinculados à economia neoclássica, segundo os quais a eficiente alocação de fatores de produção (teorema de Heckscher-Ohlin-Samuelson) ofereceria condições para o desenvolvimento de uma região, mediante a intensificação do comércio.

A lógica que impulsionou a mínero-metalurgia na região baseavase na garantia da utilização de vantagens comparativas decorrentes da possibilidade de acesso a recursos e serviços ambientais a baixo custo. Assim sendo, a viabilidade econômica da mínero-metalurgia não dependia da existência de arranjos produtivos locais, não estava ligada à necessidade de interagir com eles, de integrar-se a eles. Ora, nesses arranjos produtivos locais, além dos recursos naturais, o capital humano e o capital social são elementos essenciais para o estabelecimento de vantagens competitivas que permitam processos de desenvolvimento socialmente enraizados.

O acesso a recursos naturais a baixo custo foi determinante para que houvesse uma drástica alteração nas exportações da Amazônia oriental. O Pará, por exemplo, cujas exportações, em 1976, totalizavam US\$ 109,83 milhões, viu esse valor multiplicar-se por 34, incremento que resultou das exportações de produtos mínero-metalúrgicos; esses produtos foram responsáveis, em 2004, por $77 \%$ do valor total das exportações paraenses que, naquele ano, somaram US\$3,8 bilhões. Todavia, segundo a literatura especializada, deve-se levar em conta que a implantação de novas atividades econômicas pode elevar os níveis de produção de uma região ou de uma localidade, sem que ocorra um processo de desenvolvimento econômico e social. Parece ser esse o caso das atividades mínero-metalúrgicas, que não foram capazes de impulsionar, na Amazônia oriental brasileira, processos de desenvolvimento de base local, endógenos, socialmente enraizados, por isso, sustentáveis. Portanto, apesar do gigantismo dos volumes e cifras movimentados em decorrência da extração, do beneficiamento e da transformação industrial de recursos minerais, apesar da rápida elevação das taxas de crescimento econômico da região, apesar do favorecimento pelo aparato estatal, por meio da concessão de subsídios e de inúmeras facilidades creditícias e fiscais, apesar da aplicação de 
vultosos recursos - oriundos de fundos públicos - em infra-estrutura ou mesmo diretamente na estruturação de empresas, a mínerometalurgia não deve ser incluída entre as atividades que impulsionam dinâmicas de desenvolvimento endógeno e sustentáveis na região.

\section{VALORIZAÇÃO DE RECURSOS MINERAIS E DESENVOLVIMENTO REGIONAL}

\subsection{Dificuldades de enraizar processos de desenvolvimento}

Com as atividades mínero-metalúrgicas, criaram-se expectativas, recorrentemente acalentadas por vários segmentos da sociedade. Diversas foram as predições feitas, em diversos momentos, por planejadores oficiais que apregoavam que, com o atendimento de demandas globais de mercadorias minerais, abrir-se-ia a possibilidade para o estabelecimento de processos impulsionadores do desenvolvimento regional por meio do surgimento de uma vasta rede de relações sociais, mercantis e não mercantis, cujo elemento estruturador seria a mínerometalurgia.

Os investimentos diretos feitos pelas empresas mínero-metalúrgicas aproximam-se dos US\$ 10 bilhões, a que se somam outros investimentos em infra-estrutura, arcados por fundos públicos, que superam em muito essa cifra. Somente os custos da construção da primeira fase da Usina Hidrelétrica de Tucuruí e os encargos financeiros sobre os empréstimos que viabilizaram a obra, segundo as estimativas mais modestas, superam US\$ 7,5 bilhões. Apesar da mobilização de recursos dessa magnitude, a valorização regional de mercadorias minerais teve impacto pouco significativo no que se refere ao processo de encadeamento industrial.

A expectativa era de que ela produziria rápidos efeitos de encadeamento industrial. Entretanto, a mínero-metalurgia não foi capaz de provocar o surgimento regional da propalada rede de relações como resultado de encadeamentos "para frente e para trás" das atividades de mineração e de sídero-metalurgia. A exploração e a transformação mineral não foram capazes de propiciar a instalação de novas e diversas atividades industriais na Amazônia oriental brasileira. Assim, o caulim, o manganês e o cromo extraídos regionalmente não são submetidos a qualquer processo de transformação industrial na região. Mesmo aquela parte de minerais - como o quartzito industrial, $42,4 \%$ da bauxita e a diminuta fração do minério de ferro (6,6\%) - que é regionalmente processada, apenas o é nas etapas primárias da produção metalúrgica e siderúrgica, produzindo, respectivamente, silício metálico, alumínio pri- 
mário e ferro-gusa, que em seguida são exportados. E é irrisória a parcela de alumínio primário regionalmente transformada industrialmente e convertida em cabos para usos elétrico e siderúrgico pela empresa Alubar, localizada em Barcarena.

Uma usina de pelotização do minério de ferro, cuja instalação pela CVRD, em 2002, envolveu investimentos de US\$ 400 milhões, tem por finalidade produzir até 6 milhões de toneladas de pelotas. Trata-se de uma planta industrial edificada em função da demanda de grandes siderúrgicas que preferem pelotas ao minério de ferro. É, assim, um processo de beneficiamento que não tem como móvel fundamental processos de verticalização, em âmbito regional, da produção mineral, mas sim a adequação das características de parcela (10\%) do minério de ferro às exigências da indústria siderúrgica.

Por outro lado, a provável instalação, em São Luís, de uma aciaria para a produção anual de 3 milhões de toneladas de placas de aço não deve ser interpretada como sinal de movimento em direção à rápida verticalização da produção mineral da região, mas como parte da estratégia da mineradora de criar joint ventures com consumidores de minério de ferro, chineses, nesse caso, para instalação de novos projetos. Desse modo, a CVRD efetiva alianças que objetivam, principalmente, consolidar e ampliar fatias de mercado, como também impedir que esses consumidores migrem para outros fornecedores de minério.

As dificuldades enfrentadas pela mínero-metalurgia para impulsionar processos de desenvolvimento de base local, todavia, não residem na limitada capacidade de estabelecer encadeamento produtivo. Uma das razões é o fato de essas atividades serem profundamente dependentes de dinâmicas extra-regionais que, por sua vez, determinam os padrões tecnológicos, de inovação e de organização dentro dos quais as empresas mínero-metalúrgicas têm de operar. São lógicas que as distanciam da possibilidade de estabelecerem redes de relações sociais, econômicas, políticas e ambientais que sejam impulsionadoras de um desenvolvimento regional baseado na construção de sistemas produtivos locais, capazes de alimentar localmente dinâmicas de inovação que favoreçam o estabelecimento de processos produtivos, cujo diferencial de competitividade não esteja baseado, tão-somente, na utilização, a baixo custo, de recursos e serviços ambientais da região.

\subsection{Força de trabalho com laços tênues com as especificidades regionais}

A geração de empregos pelas mínero-metalúrgicas, fato incluído na lista dos possíveis impactos positivos decorrentes da operação des- 
sas empresas, também se mostrou pouco significativa no que se refere à possibilidade de impulsionar processos de desenvolvimento local. Foram criados aproximadamente 14 mil empregos, cujo vínculo trabalhista foi estabelecido com as próprias empresas ou por contratos estabelecidos por intermédio de outras firmas.

A incapacidade da força de trabalho demandada pela mínerometalurgia para impulsionar processos de desenvolvimento local não se deve, fundamentalmente, ao número relativamente pequeno de empregos, mas, sobretudo, ao fato de a formação requerida pelos trabalhadores envolvidos na extração e na transformação industrial de minerais ter laços muito tênues - se é que existem - com o conhecimento das especificidades locais e regionais. Por conseguinte, os processos de formação de capital humano associados às atividades mínero-metalúrgicas não são capazes de estabelecer sinergias voltadas para a apropriação, o aprimoramento e a difusão de conhecimento tácito - não formalizado em livros ou manuais -, regionalmente acumulado.

Assim, o mercado de trabalho da mínero-metalurgia, mesmo recorrendo à contratação de força de trabalho local, está assentado em relações que pouco têm contribuído para o estabelecimento de processos de desenvolvimento de base local, dependentes e formadores de capital humano.

\subsection{Políticas tributárias desvinculadas de estratégias de desenvolvimento local}

Outro aspecto que poderia ter repercussões no desenvolvimento regional seria a arrecadação de tributos decorrentes da extração e da transformação de recursos minerais.

A sociedade, por meio das estruturas estatais, poderia capturar parte do valor gerado pela mercantilização de recursos minerais regionais, que, no geral, se efetiva por meio de tributação que incide tanto sobre a extração e a comercialização, quanto sobre o lucro auferido pelas empresas responsáveis pela valorização de recursos minerais na região. Contudo, o volume da receita tributária decorrente dessas atividades é pouco significativo, se comparado ao faturamento e ao lucro dessas empresas. Isso é resultado de políticas que, mesmo elaboradas e implementadas em momentos históricos distintos, adotaram todas a sistemática renúncia fiscal no que concerne às atividades minerais. Essas práticas desenvolvidas pelo Estado nacional, pelas unidades federadas e até mesmo pelos municípios - como forma de incentivo à valorização de recursos minerais da região - terminaram por reduzir a 
incidência de impostos, taxas, contribuições ou tributos de outras ordens, limitando assim a capacidade estatal de capturar parte do valor gerado por essa atividade. Reduziu-se, assim, o volume de impostos, taxas e contribuições que poderiam originar-se da mineração.

São favores fiscais cuja oferta beneficia regiões mais desenvolvidas, pois algumas delas, por meio de relações hierarquizadas e de apropriação desigual do poder político, impulsionam políticas públicas que representam seus interesses. No caso da mínerometalurgia, a capacidade de gerar grande volume de exportações de forma regular permite a obtenção de saldos favoráveis na balança comercial, o que atende aos interesses de regiões mais desenvolvidas. Contudo, esses resultados não se coadunam necessariamente com o reforço de dinâmicas que favoreçam o desenvolvimento regional e local. Nesse contexto, favores fiscais são estabelecidos muito mais em função de interesses extra-regionais do que, efetivamente, como políticas públicas articuladas e voltadas para o desenvolvimento da região.

O principal desses favores fiscais relaciona-se com a isenção ou com a redução do imposto sobre o lucro por um período de até 10 anos. Trata-se de exceções fiscais que, em âmbito mundial, resultam do fato de os custos do capital envolvido na implantação do empreendimento mineiro tenderem a ser menores à medida que mais rapidamente forem reembolsados seus financiadores, pois, segundo a lógica do capital financeiro, como a mineração é um negócio de risco, quanto menos dilatado for o tempo de exposição do seu capital, mais reduzido será o índice que representará o "fator risco" na composição dos custos de remuneração dessa operação. Em condições nas quais se comprova a capacidade de reduzir mais rapidamente as dívidas relativas à implantação do empreendimento, o capital industrial tende a obter classificação de risco mais favorável nos empréstimos e, conseqüentemente, taxas de financiamento menores. Para tanto, o minerador procura destinar o máximo de sua renda inicial para abater dívidas e reduzir os custos financeiros.

Assim, ao construir a equação relativa à destinação das receitas originárias dos primeiros anos de operação de cada empreendimento mineiro, a empresa procura maximizar a amortização de financiamentos e, para tanto, busca fontes. Nesse contexto inserem-se as negociações com os governos voltadas para a redução, por determinado período de tempo, da incidência de tributos sobre o empreendimento (tax holidays). Na Amazônia oriental brasileira, quase todos os grandes empreendimentos mineiros contaram com esse tipo de favor fiscal. 
Todavia, se, por um lado, essas práticas fiscais atendem aos interesses do capital industrial e, em certa medida, aos de regiões mais desenvolvidas, pois são investimentos que implicam a produção de grandes saldos na balança comercial, por outro, elas não se configuraram instrumentos aptos a induzir comportamentos de empresas mineradoras capazes de impulsionar processos de desenvolvimento de caráter endógeno, mesmo levando em conta os fundamentos contratuais dessas concessões.

As políticas tributárias também evidenciam que a sociedade regional tem poder limitado para valer-se das especificidades que envolvem a valorização de recursos minerais, pois o fato de as atividades de lavra, diferentemente de outras atividades econômicas, terem de, obrigatoriamente, ser desenvolvidas na área da ocorrência mineral - o que se costuma chamar rigidez locacional - poderia resultar no estabelecimento de dinâmicas sociais que possibilitassem a elevação da tributação decorrente da valorização dessas reservas. Especialmente a ampliação da CFEM (royalties) relativa à mercantilização da hematita e da bauxita, que poderia comportar dilatação, sem comprometer a competitividade desses mercados, em decorrência das características dessas minas e dos mercados mundiais. Todavia, não é isso que ocorre.

Se, por um lado, a rigidez locacional que caracteriza a exploração das minas não é utilizada de forma eficaz por parte dos estados nacionais e membros da federação para ampliar a tributação decorrente da característica peculiar das atividades mineiras, por outro, a flexibilidade que as empresas possuem em relação às possibilidades de localização das instalações industriais nas quais se realizam etapas posteriores da transformação de bens minerais é utilizada de forma hábil por elas para que estados nacionais e membros da federação proporcionem redução de impostos para sua instalação em seus territórios. Há, de tal forma, assimetrias nas negociações que envolvem a rigidez locacional da extração e do beneficiamento primário e a flexibilidade das etapas posteriores de processamento dos minérios.

Foram, assim, configuradas estruturas, relações sociais que favorecem as empresas que têm seus interesses ligados à valorização de recursos minerais da região, o que se efetivou em detrimento de outros grupos sociais e de políticas indutoras do desenvolvimento local. Soma-se a isso o fato de que as medidas - como as que, sistematicamente, reduzem a tributação incidente sobre a mínero-metalurgia -, além de não estarem associadas a políticas de desenvolvimento endógeno, diminuem a capacidade de se capturar, por meio de tributação, parte da renda gerada por essas atividades, restringindo, por conseguinte, o vo- 
lume dos recursos, sob controle público, que poderiam ser aplicados na indução de processos de desenvolvimento local.

\subsection{Grande concentração de capitais e pouca difusão de tecnologias}

A mínero-metalurgia, em termos gerais, requer elevadíssima concentração de capitais. Alguns empreendimentos demandaram investimentos superiores a US\$ 1 bilhão, como no caso da exploração do ferro, em Carajás, da bauxita, na região do Trombetas, e da produção de alumínio primário pela Albras e pela Alumar. Todavia, o controle desses capitais é feito extra-regionalmente, o que não reforça a região como local de decisão e dela subtrai componentes relevantes para a implementação de processos de desenvolvimento socialmente enraizados.

Essa grande concentração de capitais enseja, também, de forma quase direta, concentração de renda e não colabora para que se estenda a propriedade de meios de produção a segmentos mais amplos da sociedade. Trata-se, portanto, de dinâmicas que não se coadunam com processos de desenvolvimento de base local, pois estes requerem a ampliação da eqüidade social, intimamente associada à desconcentração da renda e da propriedade de meios de produção.

Além disso, é muito elevada a composição orgânica desses capitais, ou seja, eles requerem grandes investimentos em maquinário e em infraestrutura (capital fixo), quando comparados ao volume de recursos destinados à remuneração da força de trabalho (capital variável). Todavia, a maquinaria não é produzida na região, e a tecnologia para a implantação da infra-estrutura também não é gestada regionalmente. Em ambos os casos, são trazidas para a região na forma de pacotes tecnológicos fechados. Assim, a maneira pela qual maquinaria e infraestrutura são incorporadas ao processo produtivo faz com que inexistam mecanismos significativos de difusão, para outras atividades existentes na região, da tecnologia incorporada tanto na maquinaria e nos processos de gestão quanto na infra-estrutura que serve às empresas mínerometalúrgicas.

A partir da implantação de empresas caracterizadas por elevada composição orgânica de capital, seria possível estimular processos de modernização socialmente enraizados, mas isso depende das relações entre essas empresas e suas subcontratadas. Como aponta Carleial (1997, p. 153), a forma da relação que se estabelece nessa interação pode beneficiar as empresas subcontratadas ou mesmo assumir o for- 
mato de cadeias inter-firmas, das quais podem resultar processos que auxiliam a difusão tecnológica, decisiva para o desenvolvimento regional. Entretanto, os estudos sobre as estratégias de flexibilização produtiva e de desverticalização adotadas por grandes mínero-metalúrgicas (TRINDADE, 2001; CARMO, 2000; LIMA, 2005; CORÔA FILHO, 2005) indicam que a relação de subcontratação não tem sido caracterizada por uma cooperação flexível, nem propiciado o estabelecimento de dinâmicas impulsionadoras de desenvolvimento local.

\subsection{Limitada capacidade de interagir com a diversidade local}

A extração e a transformação industrial de minerais na Amazônia oriental brasileira, em função das características dos mercados, necessitam recorrer a procedimentos industriais padronizados em termos globais. Por exemplo, a lavra da bauxita, sua transformação em alumina e posteriormente em alumínio primário, a lavra do minério de ferro, a pelotização desse minério e a produção de ferro-gusa utilizam sistemas industriais homogêneos, ou seja, são processos produtivos que replicam outros existentes no mundo. Desse imperativo decorrem limitações da mínero-metalurgia para contribuir no estabelecimento de processos de desenvolvimento de base local. Essas atividades, ao demandarem processos produtivos desenvolvidos e implementados em outros contextos sociais, culturais e ecológicos, passam a ter dificuldade de interagir com a diversidade regional, pois, a partir dessa diversidade, constituem-se realidades e atores (índios, camponeses, pequenos empresários etc.) em relação aos quais a mínero-metalurgia, com freqüência, assume uma postura conflitante e antagônica.

\subsection{Assimetrias no acesso e na mercantilização de inputs energéticos}

As diversas atividades mínero-metalúrgicas demandam energia em níveis bastante diferenciados. Essas distinções entre os fluxos energéticos são derivadas das especificidades dos processos de valorização de cada recurso mineral.

As atividades de extração e de beneficiamento primário demandam significativamente menos energia do que aquelas que envolvem a transformação industrial do mineral, como no caso do silício metálico, do ferro-gusa, do alumínio e do aço. Basta observar que a lavra, o beneficiamento primário e o transporte até o porto de uma tonelada de minério de ferro da Serra dos Carajás demandam 3,26 quilogramas equivalentes de petróleo (kgep), enquanto a produção de uma tonelada de 
ferro-gusa requer 200 vezes mais energia (659,68 kgep), suprida quase exclusivamente pelo carvão vegetal; a valorização de uma tonelada de bauxita dissipa 8,49 kgep de energia, enquanto a de uma tonelada de alumínio primário dissipa quase 540 vezes mais (MONTEIRO, 2002, p. 422).

Assim, as etapas que envolvem a transformação metalúrgica ou siderúrgica de mercadorias minerais, quando comparadas com as demais atividades de valorização regional de recursos minerais, aparecem como amplamente dependentes de inputs energéticos.

Em razão dessa diferenciação, as empresas que atuam na extração e no beneficiamento primário de minerais que demandam relativamente pequenas quantidades de energia não têm os elementos fundamentais de sua estratégia voltados para o suprimento energético. Não é, portanto, nesse campo que se concentraram suas ações para a redução e a transferência de custos. Já os interesses daquelas empresas cuja atividade demanda significativamente mais energia voltam-se para o desenvolvimento de uma série de ações que lhes viabilizam o acesso a inputs energéticos com os menores preços possíveis.

Assim, para a instalação de unidades industriais destinadas à transformação industrial de bens minerais na região - produção de alumínio primário, de silício metálico e de ferro-gusa -, foi decisiva a existência de um grande potencial hidrelétrico e de um grande volume de biomassa vegetal utilizáveis, o que possibilita o acesso a inputs energéticos capazes de viabilizar aqueles processos industriais. Já no que se refere à possível produção de aço em São Luís, trata-se, entre outros elementos, da possibilidade de ter acesso a inputs energéticos a baixo custo por meio da utilização máxima da estrutura logística de transporte transoceânico de minérios para a China, pois será possível utilizar os mesmos navios que transportam minério de ferro para importar carvão mineral destinado à produção siderúrgica.

No caso do suprimento de energia elétrica, a mercantilização do serviço ambiental representado pelo potencial hidrelétrico regional requereu diversas mediações, que envolveram o Estado nacional e empresas de atuação global, que, em última análise, transferiram para o primeiro os custos de construção da usina hidrelétrica de Tucuruí e garantiram para si preços reduzidos para a aquisição de energia elétrica. De forma semelhante, foram estabelecidas relações sociais que viabilizaram o fácil e barato acesso à biomassa originária da floresta primária para a produção de carvão vegetal utilizado como input energético no processo de valorização do ferro-gusa e do silício metálico. 
A configuração dessas relações implicou o estabelecimento de assimetrias sociais na utilização daquele serviço ambiental, como se percebe ao se inferir que a tarifa média global pela qual a Albras pagou a energia de Tucuruí não cobriu os custos de geração, o que resultou em um subsídio superior a US\$ 1 bilhão. Trata-se de um exemplo da assimetria que envolve diferenciações sociais no acesso e no uso de serviços ambientais.

Portanto, no caso da hidroeletricidade e da biomassa vegetal, foram forjadas estruturas, relações sociais que garantiram mecanismos para permitir que, com baixíssimos custos econômicos, vultosos recursos e serviços ambientais fossem convertidos em mercadorias. Nesses processos, foi decisiva a atuação do Estado nacional. É uma lógica que permite que determinados segmentos sociais apropriem-se de riqueza oriunda de fundos públicos e de vastíssimo patrimônio constituído de serviços ambientais e que existam também assimetrias entre empresas siderúrgicas e metalúrgicas e outros segmentos da sociedade no acesso e na aquisição de inputs energéticos.

\subsection{Busca de lucratividade a curto prazo e escassa prudência ambiental}

No Amapá, a exaustão das primeiras minas na região tornou mais evidente algumas dessas contradições, que se expressam na capacidade limitada da mínero-metalurgia para impulsionar processos de desenvolvimento socialmente enraizados. Tanto que naquele Estado é nítida a sensação de frustração em relação à colaboração das atividades minerais para o desenvolvimento da região. Uma frustração que toma formas concretas com a visão de diversas "crateras", como as formadas na Serra do Navio em decorrência da exploração do manganês; ou com a constatação de que, dos poucos sinais de "verticalização" da produção mineral naquele Estado, representada pela produção de ligas metálicas pela CFA, só restam os alicerces. A essa sensação agregam-se elementos mais preocupantes, pois atividades que envolvem a valorização regional de recursos minerais, ao buscarem lucratividade a curto prazo, patrocinaram práticas ambientalmente deletérias. Talvez o exemplo mais significativo dessa situação venha das constatações feitas após o fechamento das primeiras minas submetidas à exploração industrial no Amapá. Em todas essas minas, submetidas à exploração industrial e hoje exauridas, é visível, sem grande esforço, um passivo ambiental seguramente muito significativo, embora ainda não dimensionado. Um passivo cuja face mais evidente é a não-recuperação das áreas degradadas pela mineração, como se constata nos locais onde atuaram a MNA, a MYYSA e a Mineração Água Boa. Há ainda passivos ambientais mais difíceis de 
serem identificados, mas de implicações extremamente graves, como é o caso da contaminação de lençóis freáticos por arsênio, na área do porto da Icomi, ao lado da vila do Elesbão, no município de Santana, Amapá (Figura 1).

Esse problema ambiental hoje é atribuído aos rejeitos produzidos pela usina de pelotização de minério de manganês da Icomi, implantada na década de 70. Entretanto, na época de sua instalação, essa usina foi apresentada como fruto de "importantes pesquisas, desenvolvidas durante cerca de três anos nos laboratórios da empresa no Amapá e no Homer Research Laboratories, da Bethlehem Steel nos Estados Unidos" e reivindicada como um desafio vencido: "a instalação de equipamentos de alta tecnologia em plena Amazônia" (ICOMI, [1977?], p. 17). Nesse caso específico, um processo produtivo que foi apresentado à sociedade e aceito como portador de alta tecnologia e como fruto de anos de pesquisa, décadas depois se tornou uma "bomba de efeito retardado".

O assoreamento do lago Batata é fruto de lógica similar. Nos anos 90, quando a MRN já não lançava mais os rejeitos do beneficiamento da bauxita no lago, os responsáveis pelo problema argumentavam que a "ausência de tecnologia" e o "nível de consciência ecológica da época" (PLANASA, 1994, p. 67) foram alguns fatores responsáveis pelo procedimento adotado por uma década, do qual resultou um dano ambiental gravíssimo. Assim, na visão da MRN, como os avanços na tecnologia e na consciência ambiental só se efetivaram anos depois do início do processo, aquelas práticas não poderiam, naquele momento, ser tomadas como agressões ao ambiente efetuadas por negligência ou dolo, pois não haviam sido estabelecidos parâmetros sociais ou tecnológicos que as caracterizassem como tal.

Estes são alguns exemplos que indicam quão comum é a constatação de que certos procedimentos que envolvem a valorização de recursos minerais podem representar gravíssimos problemas ambientais. Entretanto, no momento em que tais procedimentos estão sendo colocados em prática, a sociedade e mesmo os próprios responsáveis pelas atividades nem sempre têm condições ou parâmetros para avaliar a existência ou mesmo a extensão dos danos decorrentes da atividade, o que, às vezes, só se constata décadas mais tarde.

Há outra dinâmica decorrente diretamente da instalação de grandes empresas mínero-metalúrgicas na região. Trata-se da atração populacional por elas desencadeada. Dela decorreram e decorrem impactos ambientais de diversas ordens, especialmente a ampliação da pressão exercida sobre os equipamentos urbanos e serviços públicos. 
Os municípios nos quais se instalaram estas empresas conviveram com elevadas taxas de crescimento anual da população. Na década de 1970, por exemplo, elas foram de 10,78\% em Almeirim; de 9,37\% em Marabá (município de cujo território surgiu, em 1988, Parauapebas); e 4,73\% em Oriximiná. Na década seguinte, Barcarena teve uma taxa de crescimento populacional por ano de 7,84\% e Marabá, mesmo com a divisão de seu território, teve crescimento populacional anual de 6,81\%.

Os impactos ambientais decorrentes das pressões populacionais não foram compensados por parte das empresas. Mesmo diante dos exemplos históricos, a quase totalidade dos processos de licenciamento ambiental para novas empresas não tem resultado no estabelecimento mecanismos de compensação pelos impactos vinculados aos fluxos populacionais decorrentes da instalação de novas empresas. Estimativas do autor indicam que a instalação, no município paraense de Juruti, de empresa voltada à valorização da bauxita, implicará em fluxo populacional do qual decorrerá a ampliação de gastos públicos para fazer face às despesas de infra-estrutura e serviços públicos decorrentes dos impactos vinculados ao crescimento populacional cujo montante, em um período de 15 anos, será de, no mínimo, R\$ 130 milhões.

Todavia, no estado do Pará, a licença de instalação desta grande mineradora, como de todas as demais mínero-metalúrgicas, foi concedida sem que fossem estabelecidos, pelo poder público, mecanismos de compensação à sociedade em relação à pressão que passa a ser exercida sobre os equipamentos urbanos e serviços públicos nos municípios onde se instalam grandes empresas do setor.

\subsection{A necessidade de se associar a mínero-metalurgia ao desenvolvimento regional}

Enfrentam-se limitações analíticas ao se buscar compreender as atividades mínero-metalúrgicas e suas repercussões nos processos de desenvolvimento regional a partir da noção de enclaves. Embora as atividades mínero-metalúrgicas não tenham se mostrado capazes de impulsionar processos de desenvolvimento de base local, elas têm impulsionado mudanças significativas na Amazônia oriental brasileira, de tal forma que deram novos contornos a algumas estruturas sociais regionalmente preexistentes, além de edificar outras. Um dos aspectos facilmente perceptíveis desse processo tem sido a proliferação, em áreas urbanas, de fornos nos quais se produz carvão vegetal a partir dos resíduos da madeira utilizada pelas serrarias para abastecer as siderúrgicas instaladas na região. Constatam-se diversas outras mudanças: fluxos migratórios ganharam novas dimensões, dinâmicas no agrário regi- 
onal sofreram alterações etc. A instalação da infra-estrutura vinculada a esses projetos, tal como a Usina Hidrelétrica de Tucuruí, também contribuiu para o estabelecimento de novas relações.

Nas extensas áreas que foram cortadas pelas ferrovias, houve modificações econômicas, sociais e ambientais. Às proximidades de cada uma das principais empresas mínero-metalúrgicas, surgiram povoados, vilas e cidades. Por exemplo, do município de Marabá, cujo território inicial abarcava a província mineral de Carajás, originaram-se os municípios de Curionópolis, Eldorado dos Carajás, Canaã dos Carajás, Água Azul do Norte e Parauapebas; todos são carentes de diversos recursos, inclusive os de infra-estrutura em saneamento básico para atender à população.

Diante de razões geológicas, históricas, de mercado e logísticas, e de um saldo questionável, devem-se ampliar as reflexões acerca das condições nas quais é possível converter os recursos minerais da região em vetores de desenvolvimento. Em especial porque a mínerometalurgia, na primeira década deste século, será a atividade que realizará o maior volume de investimentos na Amazônia oriental brasileira.

Há de se considerar que se trata de agentes sociais e econômicos que têm sua trajetória marcada pelo reforço de um projeto de desenvolvimento regional assentado na concentração da renda, na homogeneização dos processos produtivos e na valorização pouco qualificada do capital natural da região. Os habitus desses agentes sociais e econômicos (BOURDIEU, 2003, p. 199) os distanciam da possibilidade de estabelecerem redes de relações sociais, econômicas, políticas e ambientais que sejam impulsionadoras do desenvolvimento regional, com a construção de sistemas produtivos locais capazes de alimentar localmente dinâmicas de inovação que favoreçam processos produtivos cuja competitividade não esteja baseada, tão-somente, na utilização, a baixo custo, de recursos e serviços ambientais da região.

Dessa forma, as ações do Governo Federal e de amplos segmentos da sociedade diante dessas empresas mínero-metalúrgicas não podem ser interpretadas como neutras em relação aos desdobramentos dos processos de desenvolvimento em curso na Amazônia. Assim, é necessária a criação de uma ambiência social que favoreça e possibilite um rígido controle ambiental das atividades mínero-metalúrgicas. E a concessão de licenças ambientais de grandes empreendimentos mínerometalúrgicos deve levar em consideração a necessidade da compensação ambiental pelos impactos decorrentes do elevado crescimento populacional vinculado à instalação destas empresas. É preciso evitar a 
prática da transferência de custos privados para a sociedade e, sobretudo, criar uma tensão que busque bloquear comportamentos oportunistas, no que se refere à transferência de custos privados para a sociedade, e que induza a adoção de mecanismos de inovação para a garantia da competitividade.

Quanto à questão fiscal e tributária, se, por um lado, a renúncia fiscal é benéfica, em nome do esforço exportador e, em certos casos, permite a participação no mercado internacional de uma empresa mínero-metalúrgica, por outro, essa renúncia fiscal, especialmente se se levar em conta que os fundamentos de tais concessões são contratuais, pode ser um instrumento apto a induzir empresas mineradoras a adotar comportamentos que impulsionem processos de desenvolvimento de caráter endógeno, como a cooperação técnica interempresas, o estabelecimento de mecanismos de difusão tecnológica, a formação de cadeias de subcontratação que possam vir a favorecer o desenvolvimento local etc.

Também é viável associar a mínero-metalurgia ao desenvolvimento local por meio da ampliação, mediante tributação, lato sensu, da parte do valor criado pela mineração. A ampliação das alíquotas dos royalties, por exemplo, não comprometeria a competitividade internacional das commodities, uma vez que se encontram bem abaixo da média mundial. Poderiam ser recursos destinados ao fortalecimento de processos de desenvolvimento fundamentados em vantagens competitivas socialmente criadas e integradas ao uso sustentável da base natural da região.

Trata-se de uma possibilidade. Todavia, ainda se está distante da sua concretização, uma vez que isso implica confronto com interesses econômicos, visões de mundo, com o tradicionalismo de diversas ordens e instituições, etc. É preciso que os dirigentes políticos tenham firmeza e clareza estratégica, que se instaure uma institucionalidade pública na Amazônia permeável à pluralidade de forças que expressam a sua diversidade social e cultural e, sobretudo, que se mobilizem os diversos segmentos sociais comprometidos com um novo tipo de desenvolvimento regional. 


\section{REFERÊNCIAS}

ALMEIDA JR., José Maria Gonçalves (Org.). Carajás: desafio político e desenvolvimento. São Paulo: Brasiliense, CNPq, 1986.

ARTHUR, W. B. Increasing returns and path dependence in the economy. Michigan: The University of Michigan Press, 2000.

BOURDIEU, Pierre. O poder simbólico. 6. ed. Rio de Janeiro: Bertrand Brasil, 2003. 322p.

BRASIL. Ministério do Planejamento e Orçamento. Projeto de Desenvolvimento Integrado da Região Norte. Brasília: Universa, 1997a.

. Indicações para uma nova estratégia de desenvolvimento regional. Brasília: Universidade Católica de Brasília, 1997b.

- Ministério da Integração Nacional. Política Nacional de Desenvolvimento Regional: proposta para discussão. Brasília, 2003a. - Ministério do Planejamento e Orçamento e Gestão. Plano Plurianual 2004-2007. Brasília, 2003b.

Ministério do Planejamento e Orçamento e Gestão. Projeto de Desenvolvimento Integrado da Região Norte. Brasília: Universidade Católica de Brasília, 1997a.

. Ministério da Integração Nacional, Ministério do Meio Ambiente.

Plano Amazônia Sustentável (PAS): diagnóstico e estratégia. Brasília, abr. 2004, v. 1. 113 p.

. Presidência da República. Secretaria de Imprensa e Divulgação.

Grande Carajás. Brasília, 1982. 35p.

CARLEIAL, Liana Maria da Frota. Sistemas regionais de inovação e relação entre firmas: as "pistas" para um formato de desenvolvimento regional. Revista Econômica do Nordeste, Fortaleza, v. 28, p. 143-168, jul. 1997. (Número Especial).

CARMO, E. D. Gestão do trabalho na Indústria de Alumínio ALBRAS: Noção de qualidade e seus interlocutores. Belém: NAEA/UFPA, 2000. 251p.

CASTRO, Edna M. R. de; MOURA, Edila; MAIA, Maria Lúcia Sá. Industrialização e grandes projetos: desorganização e reorganização do espaço. Belém: UFPA, 1994.

CHANDLER JR., Alfred Dupont. The visible hand: the managerial revolution in American business. Massachussetts: Harvard University Press, 1977. 
COELHO, Maria Célia Nunes; COTA, Raymundo Garcia (Org.). Dez anos da Estrada de Ferro Carajás. Belém: NAEA/UFPA, 1997. 356p.

COLEMAN, J. Foundations of social theory. Cambridge: The Belknap Press of Harvard University Press, 1990.

CORÔA FILHO, Vicente Uparajara. Redes de subcontratação e desenvolvimento local: a atuação da Albras no arranjo produtivo de Barcarena. 2005. 137f. Dissertação (Mestrado em Planejamento do Desenvolvimento) - Núcleo de Altos Estudos Amazônicos, Universidade Federal do Pará, Belém, 2005.

CUNHA, Álvaro da. Quem explorou quem no contrato do manganês do Amapá. Macapá: Rumo, 1962.

CVRD; LMSA. Projeto Alumínio na Região Amazônica. Relatório Preliminar. Brasília, 1974.

D'INCAO, Maria Angela; SILVEIRA, Isolda Maciel da (Org.). A Amazônia e a crise da modernização. Belém: Museu Paraense Emílio Goeldi, 1994 (Coleção Eduardo Galvão).

DOSI et al. Technical changes and economy theory. London: Pinter Publishers, 1988.

FREEMAN, C. The economics of technical change. Cambridge Journal of Economics. v. 8, n. 1, 1994. p. 3-22.

HALL, Anthony l. Amazônia: desenvolvimento para quem? Desmatamento e conflito social no Programa Grande Carajás. Rio de Janeiro: Jorge Zahar, 1991. 300p.

HALWARD et al. Comparação entre algumas propriedades físico-químicas do caulim Amazonas 88 e de outros caulins. Revista Brasileira de Tecnologia, Brasília, v. 8, n. 1/2, p. 83-95, mar./jun. 1977.

HIRSCHMAN, A. O. The strategy of economic development. New Haven: Yale University Press, 1958.

ICOMI. O manganês do Amapá - 1975/1976. Macapá: Grupo Caemi, [1977?]. 24p.

KRUGMAN, P. Development, geography, and economy theory. Cambridge: The MIT Press, 1995.

LIMA, Marco Antonio Silva. Relações inter-firmas em Barcarena/PA: um estudo das práticas de inovação e cooperação na rede de fornecedores e subcontratados da IRCC. 2005. 137f. Dissertação (Mestrado em Planejamento do Desenvolvimento) - Núcleo de Altos Estudos Amazônicos, Universidade Federal do Pará, Belém, 2005. 
LIMA, Marcelo de Oliveira et al. Estudo da disperção do Ar no meio físico na área de estocagem de minério de Mn e adjacências no município de Santana, estado do Amapá. In: SEMINÁRIO 50 ANOS DE MINERAÇÃO INDUSTRIAL NA AMAZÔNIA, 1. , 2002, Macapá. Resumos... Belém: NAEA/UFPA, 2002 p. 37-38.

MACHADO, R. C. Apontamentos da história do alumínio primário no Brasil. Ouro Preto: Fundação Gorceix, 1985.

MNA. Relatório anual de lavra 1989. Rio de Janeiro: MNA, 1988.

MIRANDA, Antônio Marcos Mota. Avaliação da exposição ao As associado ao rejeito de MN (Mineração) no estado do Amapá: abordagem da sáude humana. In: SEMINÁRIO 50 ANOS DE MINERAÇÃO INDUSTRIAL NA AMAZÔNIA, 1. 2002, Macapá. Resumos... Belém: NAEA/UFPA, 2002 p. 35-36.

MONTEIRO, Maurílio. Siderurgia e carvoejamento na Amazônia: drenagem energético-material e pauperização regional. Belém: NAEA/UFPA, 1998. 251 p.

Mineração e metalurgia na Amazônia: contribuição à crítica da ecologia política à valorização de recursos minerais da região. 2000. $524 f$. Tese (Desenvolvimento Sustentável do Trópico Úmido) - Núcleo de Altos Estudos Amazônicos, Universidade Federal do Pará, Belém, 2000.

Problemas e perspectivas da verticalização da produção da hematita na Amazônia oriental brasileira: o caso da produção de ferro-gusa. In: KLEIN, E. L.; VASQUEZ, M. L.; ROSA-COSTA, L. T. (Org.). Contribuições à geologia da Amazônia. Belém: Sociedade Brasileira de Geologia - Núcleo Norte (SBG - NO), 2002, v. 3. p. 23-32.

PERROUX, François. A economia do século XX. Lisboa: Livraria Morais, 1967. p. 143-311.

PINTO, José Armindo et al. Garimpo do Lourenço: um século de conflitos na extração do ouro. Macapá, 1999. 81 p. il. Mimeografado.

PLANASA. Companhia Ferro-Ligas do Amapá (CFA). Projeto de Implantação. Belém, 1987.

úmida e seca. Belém, 1994.

PROMineR. Mineração Yukio Yoshidome S.A. Plano de reabilitação ambiental. São Paulo, 1989.

ROMER, P. M. The origins of endogenous growth. Journal of Economic Perspectives, v. 18, n.1, 1994.

SILVA, José de Cupertino. Participação econômica do Estado brasileiro no Programa Grande Carajás. Uma análise qualitativa ex-ante. Belém: NAEA/UFPA, 1982/1992(?). p. 73. 
SUDAM. Programa de pólos agropecuários e agrominerais da Amazônia: Poloamazônia - Síntese. Belém, 1975. 105p.

. II Plano de Desenvolvimento da Amazônia. Detalhamento do II Plano Nacional de Desenvolvimento (1975-1979). Belém: Divisão de Documentação, 1976. 334p.

TRINDADE, José Raimundo Barreto. A metamorfose do trabalho na Amazônia: para além da Mineração Rio do Norte. Belém: NAEA/UFPA, 1997/ 2001.

VIVACQUIA; Paulo Augusto et al. O Brasil e o alumínio. Atuação da CVRD. Mineração e Metalurgia, Rio de Janeiro, v. 45, n. 428, jun. 1981. 